\title{
The Role of Fe, Zn, and Cu in Pregnancy
}

\author{
Konrad Grzeszczak $^{1}\left[\right.$, Sebastian Kwiatkowski ${ }^{2}$ and Danuta Kosik-Bogacka ${ }^{3, *}$ (] \\ 1 Department of Biology and Medical Parasitology, Pomeranian Medical University in Szczecin, Powstańców \\ Wielkopolskich 72,70-111 Szczecin, Poland; konrad.grzeszczak@pum.edu.pl \\ 2 Department of Obstetrics and Gynecology, Pomeranian Medical University in Szczecin, Powstańców \\ Wielkopolskich 72, 70-111 Szczecin, Poland; kwiatkowskiseba@gmail.com \\ 3 Independent Laboratory of Pharmaceutical Botany, Pomeranian Medical University in Szczecin, \\ Powstańców Wielkopolskich 72, 70-111 Szczecin, Poland \\ * Correspondence: kodan@pum.edu.pl; Tel.: +48-605103907
}

Received: 12 June 2020; Accepted: 5 August 2020; Published: 12 August 2020

\begin{abstract}
Iron $(\mathrm{Fe})$, copper $(\mathrm{Cu})$, and zinc $(\mathrm{Zn})$ are microelements essential for the proper functioning of living organisms. These elements participatein many processes, including cellular metabolism and antioxidant and anti-inflammatory defenses, and also influence enzyme activity, regulate gene expression, and take part in protein synthesis. $\mathrm{Fe}, \mathrm{Cu}$, and $\mathrm{Zn}$ have a significant impact on the health of pregnant women and in the development of the fetus, as well as on the health of the newborn. A proper concentration of these elements in the body of women during pregnancy reduces the risk of complications such as anemia, induced hypertension, low birth weight, preeclampsia, and postnatal complications. The interactions between $\mathrm{Fe}, \mathrm{Cu}$, and $\mathrm{Zn}$ influence their availability due to their similar physicochemical properties. This most often occurs during intestinal absorption, where metal ions compete for binding sites with transport compounds. Additionally, the relationships between these ions have a great influence on the course of reactions in the tissues, as well as on their excretion, which can be stimulated or delayed. This review aims to summarize reports on the influence of Fe, $\mathrm{Cu}$, and $\mathrm{Zn}$ on the course of single and multiple pregnancies, and to discuss the interdependencies and mechanisms occurring between $\mathrm{Fe}, \mathrm{Cu}$, and $\mathrm{Zn}$.
\end{abstract}

Keywords: microelements; iron; copper; zinc; pregnancy

\section{Introduction}

Macroelements and microelements are essential for the proper functioning of living organisms (Figure 1). They participatein many processes, including cellular metabolism and antioxidant and anti-inflammatory defenses, and also influence enzyme activity, regulate gene expression, and take part in protein synthesis [1]. Provided in the diet, their levels in the human body depend on the geographical location, environmental pollution, gender, and age. A considerable body of research has been devoted to the concentrations of iron $(\mathrm{Fe})$, copper $(\mathrm{Cu})$, and zinc $(\mathrm{Zn})$ in biological materials from women during childbirth, including fetal membrane (FM) and serum (FS), cord blood(CB), serum (CS) and plasma (CP), and maternal blood(MB), serum (MS) and plasma (MP), and placenta (P) (Table 1). 
Table 1. The concentrations of iron (Fe), copper $(\mathrm{Cu})$, and zinc $(\mathrm{Zn})$ in different biological materials collected from women during childbirth $(n$, number of women; FM, fetal membrane; FS, fetal serum; C, cord; CB, cord blood; CS, cord serum; CP, cord plasma MB, maternal blood; MS, maternal serum; MP, maternal plasma; P, placenta; $\mathrm{dw}$, dry weight; ww, wet weight).

\begin{tabular}{|c|c|c|c|c|c|c|}
\hline \multirow{2}{*}{ Research Area } & \multirow{2}{*}{$n$} & \multirow{2}{*}{ Mean Age (Years) } & \multicolumn{3}{|c|}{ Concentration of } & \multirow{2}{*}{ References } \\
\hline & & & $\mathrm{Fe}$ & $\mathrm{Cu}$ & Zn & \\
\hline \multicolumn{7}{|c|}{ Europe } \\
\hline Szczecin, Poland & 170 & 29 & $\begin{array}{l}\text { P: } 640.726 \mathrm{mg} / \mathrm{kg} \mathrm{dw} \\
\text { FM: } 640.726 \mathrm{mg} / \mathrm{kg} \mathrm{dw} \\
\text { C: } 567.285 \mathrm{mg} / \mathrm{kg} \mathrm{dw}\end{array}$ & $\begin{array}{l}\text { P: } 6.013 \mathrm{mg} / \mathrm{kg} \mathrm{dw} \\
\text { FM: } 8.906 \mathrm{mg} / \mathrm{kg} \mathrm{dw} \\
\text { C: } 4.320 \mathrm{mg} / \mathrm{kg} \mathrm{dw}\end{array}$ & $\begin{array}{l}\text { P: } 66.904 \mathrm{~g} / \mathrm{kg} \mathrm{dw} \\
\text { FM: } 62.788 \mathrm{~g} / \mathrm{kg} \mathrm{dw} \\
\text { C: } 54.653 \mathrm{~g} / \mathrm{kg} \mathrm{dw}\end{array}$ & {$[2]$} \\
\hline Poznan, Poland & 64 & 28.1 & $\begin{array}{c}\text { MS: } 1.08 \mu \mathrm{g} / \mathrm{mL} \\
\text { CS (vein): } 1.96 \mu \mathrm{g} / \mathrm{mL} \\
\text { CS (artery): } 1.63 \mu \mathrm{g} / \mathrm{mL}\end{array}$ & $\begin{array}{c}\text { MS: } 0.63 \mu \mathrm{g} / \mathrm{mL} \\
\text { CS (vein): } 0.65 \mu \mathrm{g} / \mathrm{mL} \\
\text { CS (artery): } 0.65 \mu \mathrm{g} / \mathrm{mL}\end{array}$ & $\begin{array}{c}\text { MS: } 1.91 \mu \mathrm{g} / \mathrm{mL} \\
\text { CS (vein): } 0.36 \mu \mathrm{g} / \mathrm{mL} \\
\text { CS (artery): } 0.36 \mu \mathrm{g} / \mathrm{mL}\end{array}$ & [3] \\
\hline Oleśnica, Poland & 64 & 27 & - & $\begin{array}{l}\text { MP: } 1.93 \mathrm{mg} / \mathrm{L} \\
\text { CP: } 0.49 \mathrm{mg} / \mathrm{L}\end{array}$ & $\begin{array}{l}\text { MP: } 0.58 \mathrm{mg} / \mathrm{L} \\
\text { CP: } 0.82 \mathrm{mg} / \mathrm{L}\end{array}$ & [4] \\
\hline \multirow{2}{*}{$\begin{array}{c}\text { Sverdlovsk region } \\
\text { (non-industrial areas) } \\
\text { andYekaterinburg } \\
\text { (industrial city), Russian }\end{array}$} & $\begin{array}{l}\text { Pregnant women from } \\
\text { non-industrial areas (29) }\end{array}$ & \multirow{2}{*}{ Age range: $17-42$} & - & $\begin{array}{l}\text { MS: } 5.44 \mathrm{mkg} / \mathrm{mL} \\
\text { P: } 6.1 \mathrm{mkg} / \mathrm{mL}\end{array}$ & - & \multirow{2}{*}{ [5] } \\
\hline & $\begin{array}{l}\text { Pregnant women from } \\
\text { industrial city (127) }\end{array}$ & & - & $\begin{array}{l}\text { MS: } 4.73 \mathrm{mkg} / \mathrm{mL} \\
\text { P: } 13.34 \mathrm{mkg} / \mathrm{mL}\end{array}$ & - & \\
\hline \multirow{4}{*}{ Moscow, Russian } & (150) control & 33.1 & MS: $1.34 \mu \mathrm{g} / \mathrm{L}$ & MS: $1.15 \mu \mathrm{g} / \mathrm{L}$ & - & \multirow{4}{*}[6]{} \\
\hline & Pregnancy (169) & 33.4 & MS: $1.27 \mu \mathrm{g} / \mathrm{L}$ & MS:1.60 $\mu \mathrm{g} / \mathrm{L}$ & - & \\
\hline & Miscarriage (75) & 34.8 & MS: $1.43 \mu \mathrm{g} / \mathrm{L}$ & MS: $1.12 \mu \mathrm{g} / \mathrm{L}$ & - & \\
\hline & Infertility (91) & 35.5 & MS: $1.29 \mu \mathrm{g} / \mathrm{L}$ & MS:1.04 $\mu \mathrm{g} / \mathrm{L}$ & - & \\
\hline \multirow{3}{*}{ Barcelona, Spain } & $\begin{array}{l}\text { Appropriate for gestational } \\
\text { age (96) }\end{array}$ & 32 & - & - & $\begin{array}{l}\text { MS: } 1181 \mu \mathrm{g} / \mathrm{dL} w w \\
\text { FS: } 1518 \mu \mathrm{g} / \mathrm{dL} \text { ww } \\
\text { P: } 8.4 \mu \mathrm{g} / \mathrm{dL} w w\end{array}$ & \multirow{3}{*}{ [7] } \\
\hline & $\begin{array}{l}\text { Intrauterine growth } \\
\text { restriction (49) }\end{array}$ & 32 & - & - & $\begin{array}{l}\text { MS: } 935 \mu \mathrm{g} / \mathrm{dL} w w \\
\text { FS: } 935 \mu \mathrm{g} / \mathrm{dL} w w \\
\text { P: } 8.5 \mu \mathrm{g} / \mathrm{dL} w w\end{array}$ & \\
\hline & $\begin{array}{l}\text { Small for gestational } \\
\text { age (33) }\end{array}$ & 30 & - & - & $\begin{array}{l}\text { MS: } 984 \mu \mathrm{g} / \mathrm{dL} w w \\
\text { FS: } 1134 \mu \mathrm{g} / \mathrm{dL} w w \\
\text { P: } 8.9 \mu \mathrm{g} / \mathrm{dL} w w\end{array}$ & \\
\hline
\end{tabular}


Table 1. Cont

\begin{tabular}{|c|c|c|c|c|c|c|}
\hline \multicolumn{7}{|c|}{ Africa } \\
\hline $\begin{array}{c}\text { Mid-Western Region, } \\
\text { Nigeria }\end{array}$ & 22 & - & P: $84.3 \mu \mathrm{g} / \mathrm{gm} \mathrm{dw}$ & $\mathrm{P}: 6.3 \mu \mathrm{g} / \mu \mathrm{m} \mathrm{dw}$ & $\mathrm{P}: 66.6 \mu \mathrm{g} / \mu \mathrm{m} \mathrm{dw}$ & {$[8]$} \\
\hline \multicolumn{7}{|c|}{ North America } \\
\hline New Hampshire, USA & 1159 & 31.2 & - & - & $\mathrm{P}: 10.26 \mu \mathrm{g} / \mathrm{g}$ ww & [9] \\
\hline Las Vegas, Nevada, USA & 28 & 29.9 & $\mathrm{P}: 1185.18 \mu \mathrm{g} / \mathrm{L} \mathrm{dw}$ & P: $7.81 \mu \mathrm{g} / \mathrm{L} \mathrm{dw}$ & $\mathrm{P}: 63.59 \mu \mathrm{g} / \mathrm{L} \mathrm{dw}$ & [10] \\
\hline \multirow{2}{*}{ New York, USA } & $\begin{array}{l}\text { Women carrying } \\
\text { multiples (101) }\end{array}$ & 30 & P: $26.63 \mu \mathrm{g} / \mathrm{g} \mathrm{dw}$ & - & P: $5.9 \mu \mathrm{g} / \mathrm{g} \mathrm{dw}$ & \multirow{2}{*}{ [11] } \\
\hline & $\begin{array}{l}\text { Women carrying } \\
\text { singletons (132) }\end{array}$ & 17.4 & P: $17.99 \mu \mathrm{g} / \mathrm{g} \mathrm{dw}$ & - & P: $2.6 \mu \mathrm{g} / \mathrm{g} \mathrm{dw}$ & \\
\hline Chattanooga, USA & 374 & - & P: $503,200 \mu \mathrm{g} / \mathrm{kg} \mathrm{dw}$ & $\mathrm{P}: 3889 \mu \mathrm{g} / \mathrm{kg} \mathrm{dw}$ & $\mathrm{P}: 55,120 \mu \mathrm{g} / \mathrm{kg} \mathrm{dw}$ & [12] \\
\hline \multirow{2}{*}{ Pune, India } & Normal pregnancies (47) & \multirow{2}{*}{ Age range: 19-35 } & $\begin{array}{l}\text { MB: } 120.4 \mu \mathrm{g} / \mathrm{dL} \\
\text { CB: } 153.4 \mu \mathrm{g} / \mathrm{dL}\end{array}$ & $\begin{array}{l}\text { MB: } 1.44 \mu \mathrm{g} / \mathrm{dL} \\
\text { CB: } 0.26 \mu \mathrm{g} / \mathrm{dL}\end{array}$ & $\begin{array}{l}\text { MB: } 57.5 \mu \mathrm{g} / \mathrm{dL} \\
\text { CB: } 90.8 \mu \mathrm{g} / \mathrm{dL}\end{array}$ & \multirow{2}{*}{13} \\
\hline & $\begin{array}{c}\text { Preeclamptic } \\
\text { pregnancies (14) }\end{array}$ & & $\begin{array}{l}\text { MB: } 96.3 \mu \mathrm{g} / \mathrm{dL} \\
\text { CB: } 118.6 \mu \mathrm{g} / \mathrm{dL}\end{array}$ & $\begin{array}{l}\text { MB: } 1.58 \mu \mathrm{g} / \mathrm{dL} \\
\text { CB: } 0.81 \mu \mathrm{g} / \mathrm{dL}\end{array}$ & $\begin{array}{l}\text { MB: } 49.2 \mu \mathrm{g} / \mathrm{dL} \\
\text { CB:79.9 } \mathrm{g} / \mathrm{dL}\end{array}$ & \\
\hline \multirow{2}{*}{ Delhi, India } & $\begin{array}{l}\text { Females delivered full term } \\
\text { babies (gestational age } \\
>37 \text { weeks) (50) }\end{array}$ & 25.54 & P: $58.94 \mu \mathrm{g} / \mathrm{dL} \mathrm{dw}$ & $\mathrm{P}: 0.255 \mu \mathrm{g} / \mathrm{dL} \mathrm{dw}$ & P: $18.28 \mu \mathrm{g} / \mathrm{dL} \mathrm{dw}$ & \multirow{2}{*}{14} \\
\hline & $\begin{array}{c}\text { Females delivered pre-term } \\
\text { babies (gestational age } \\
<37 \text { weeks) (30) }\end{array}$ & 24.63 & $\mathrm{P}: 50.60 \mu \mathrm{g} / \mathrm{dL} \mathrm{dw}$ & P: $0.220 \mu \mathrm{g} / \mathrm{dL} \mathrm{dw}$ & $\mathrm{P}: 17.26 \mu \mathrm{g} / \mathrm{dL} \mathrm{dw}$ & \\
\hline \multirow{2}{*}{ Jaipur, India } & Pregnant women (80) & 29.8 & P: $72.7 \mu \mathrm{g} / \mathrm{dL}$ & $\mathrm{P}: 187.3 \mu \mathrm{g} / \mathrm{dL}$ & $\mathrm{P}: 70.5 \mu \mathrm{g} / \mathrm{dL}$ & \multirow{2}{*}{15} \\
\hline & Non-pregnant women (20) & 20 & P: $106.9 \mu \mathrm{g} / \mathrm{dL}$ & $\mathrm{P}: 127.7 \mu \mathrm{g} / \mathrm{dL}$ & $\mathrm{P}: 100.9 \mu \mathrm{g} / \mathrm{dL}$ & \\
\hline \multirow{2}{*}{ Ahmedabad, India } & $\begin{array}{c}\text { Women with spontaneous } \\
\text { abortion(159) }\end{array}$ & 24.85 & - & MS: $1.59 \mathrm{mg} / \mathrm{L}$ & MS: $1.43 \mathrm{mg} / \mathrm{L}$ & \multirow{2}{*}{16} \\
\hline & $\begin{array}{l}\text { Woman without } \\
\text { spontaneous abortion (118) }\end{array}$ & 23.65 & - & MS: $1.81 \mathrm{mg} / \mathrm{L}$ & MS: 1.46 mg/L & \\
\hline
\end{tabular}


Table 1. Cont.

\begin{tabular}{|c|c|c|c|c|c|c|}
\hline \multirow{2}{*}{ Hyderabad, India } & $\begin{array}{l}\text { Pregnant women from } \\
\text { rural area (30) }\end{array}$ & 21.1 & $\begin{array}{l}\text { MS: } 201.6 \mu \mathrm{g} / \mathrm{dL} \\
\text { CS: } 279.8 \mu \mathrm{g} / \mathrm{dL} \\
\text { P: } 1159.5 \mu \mathrm{g} / \mathrm{g}\end{array}$ & $\begin{array}{l}\text { MS: } 166.6 \mu \mathrm{g} / \mathrm{dL} \\
\text { CS: } 92.03 \mu \mathrm{g} / \mathrm{dL} \\
\text { P: } 78.4 \mu \mathrm{g} / \mathrm{g}\end{array}$ & $\begin{array}{l}\text { MS: } 205.1 \mu \mathrm{g} / \mathrm{dL} \\
\text { CS: } 128.2 \mu \mathrm{g} / \mathrm{dL} \\
\text { P: } 49.6 \mu \mathrm{g} / \mathrm{g}\end{array}$ & \multirow{2}{*}{ [17] } \\
\hline & $\begin{array}{l}\text { Pregnant women from } \\
\text { urban area (30) }\end{array}$ & 22.2 & $\begin{array}{l}\text { MS: } 128.6 \mu \mathrm{g} / \mathrm{dL} \\
\text { CS: } 200.3 \mu \mathrm{g} / \mathrm{dL} \\
\text { P: } 1458.2 \mu \mathrm{g} / \mathrm{g}\end{array}$ & $\begin{array}{l}\text { MS: } 150.7 \mu \mathrm{g} / \mathrm{dL} \\
\text { CS: } 83.5 \mu \mathrm{g} / \mathrm{dL} \\
\text { P: } 61.4 \mu \mathrm{g} / \mathrm{g}\end{array}$ & $\begin{array}{l}\text { MS: } 245.6 \mu \mathrm{g} / \mathrm{dL} \\
\text { CS: } 122.1 \mu \mathrm{g} / \mathrm{dL} \\
\text { P: } 51.5 \mu \mathrm{g} / \mathrm{g}\end{array}$ & \\
\hline \multirow{2}{*}{ Jakarta, Indonesia } & $\begin{array}{l}\text { Pregnant womens } \\
\geq 37 \text { weeks of gestational } \\
\text { age for the term group ( } 25)\end{array}$ & 27.68 & $\begin{array}{c}\text { P: } 252.16 \mu \mathrm{g} / \mathrm{g} \mathrm{dw} \\
\text { CB: } 212.00 \mu \mathrm{g} / \mathrm{dL} \mathrm{dw} \\
\text { MS: } 77 \mu \mathrm{g} / \mathrm{dL} \mathrm{dw}\end{array}$ & $\begin{array}{c}\text { P: } 2.96 \mu \mathrm{g} / \mathrm{g} \mathrm{dw} \\
\text { CB: } 32.20 \mu \mathrm{g} / \mathrm{dL} \mathrm{dw} \\
\text { MS: } 222.65 \mu \mathrm{g} / \mathrm{dL} \mathrm{dw}\end{array}$ & $\begin{array}{c}\text { P: } 58.34 \mu \mathrm{g} / \mathrm{g} \mathrm{dw} \\
\text { CB: } 293.80 \mu \mathrm{g} / \mathrm{dL} \mathrm{dw} \\
\text { MS: } 45.16 \mu \mathrm{g} / \mathrm{dL} \mathrm{dw}\end{array}$ & \multirow{2}{*}{18} \\
\hline & $\begin{array}{l}\text { Pregnant womens preterm } \\
\text { birth in } 26-36 \text { weeks of } \\
\text { gestational age (26) }\end{array}$ & 24.0 & $\begin{array}{c}\text { P: } 78.45 \mu \mathrm{g} / \mathrm{g} \mathrm{dw} \\
\text { CB: } 236.50 \mu \mathrm{g} / \mathrm{dL} \mathrm{dw} \\
\text { MS: } 71.50 \mu \mathrm{g} / \mathrm{dL} \mathrm{dw}\end{array}$ & $\begin{array}{c}\text { P: } 1.62 \mu \mathrm{g} / \mathrm{g} \mathrm{dw} \\
\text { CB: } 20.60 \mu \mathrm{g} / \mathrm{dL} \mathrm{dw} \\
\text { MS: } 215.35 \mu \mathrm{g} / \mathrm{dL} \mathrm{dw}\end{array}$ & $\begin{array}{l}\text { P: } 28.41 \mu \mathrm{g} / \mathrm{g} \mathrm{dw} \\
\text { CB: } 321.43 \mu \mathrm{g} / \mathrm{dL} \mathrm{dw} \\
\text { MS: } 40.26 \mu \mathrm{g} / \mathrm{dL} \mathrm{dw}\end{array}$ & \\
\hline Fukuoka, Japan & 48 & 29.3 & - & $\begin{array}{l}\text { P: } 3910 \mathrm{ng} / \mathrm{g} \mathrm{dw} \\
\text { C: } 2960 \mathrm{ng} / \mathrm{g} \mathrm{dw}\end{array}$ & $\begin{array}{l}\text { P: } 48,100 \mathrm{ng} / \mathrm{g} \mathrm{dw} \\
\text { C: } 35,700 \mathrm{ng} / \mathrm{g} \mathrm{dw}\end{array}$ & [19] \\
\hline Shanghai, China & 1568 & 26.4 & MS: $8.1 \mathrm{mmol} / \mathrm{L}$ & MS: $23.43 \mu \mathrm{mol} / \mathrm{L}$ & MS: $87.32 \mu \mathrm{mol} / \mathrm{L}$ & [20] \\
\hline Amman, Jordan & 92 & 27 & CB: $116 \mu \mathrm{g} / \mathrm{dL}$ & CB: $49 \mu \mathrm{g} / \mathrm{dL}$ & $\mathrm{CB}: 114 \mu \mathrm{g} / \mathrm{dL}$ & [21] \\
\hline
\end{tabular}




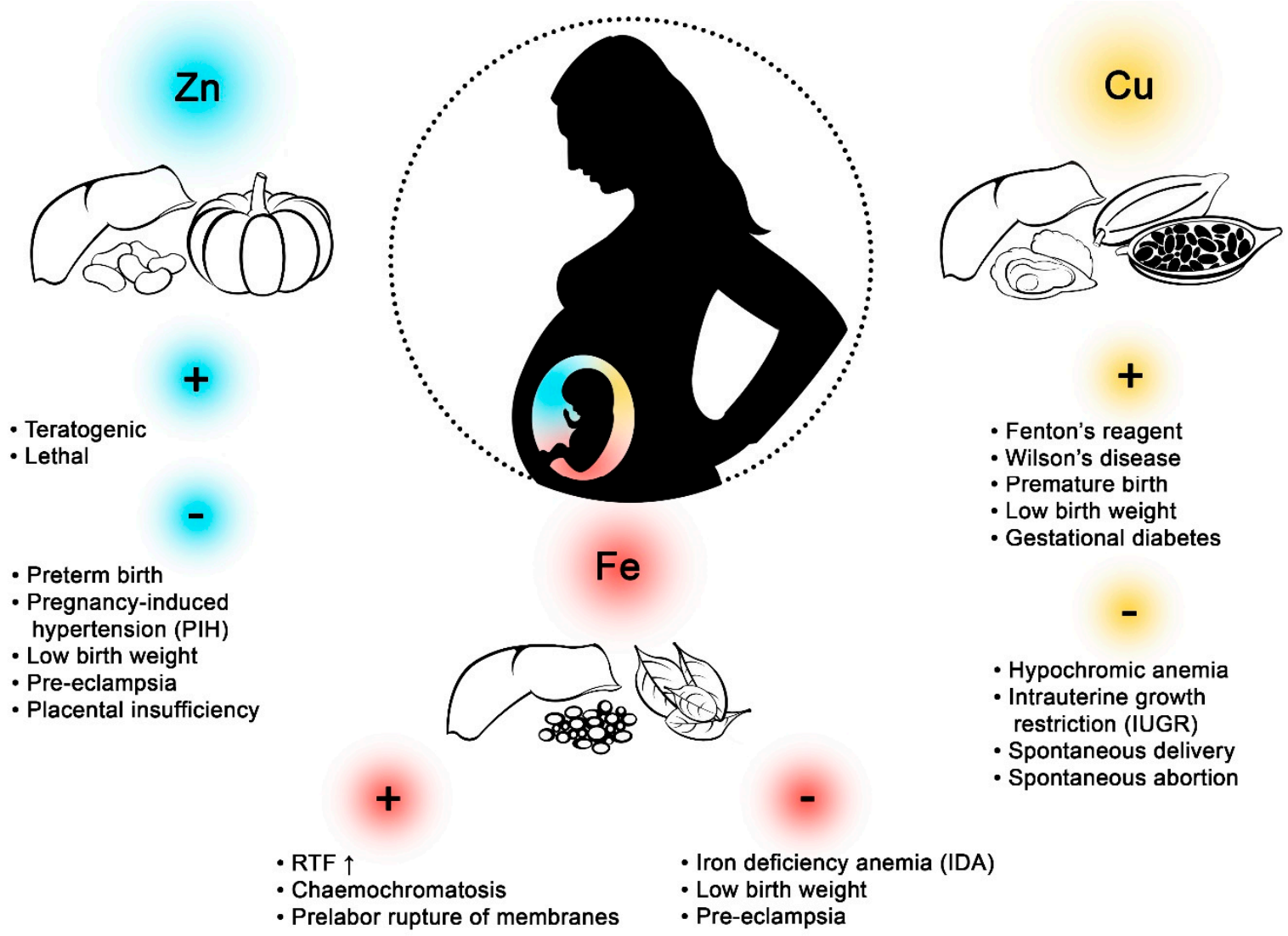

Figure 1. Effects of zinc $(\mathrm{Zn})$, copper $(\mathrm{Cu})$, and iron $(\mathrm{Fe})$ on pregnant women. Excess $\mathrm{Zn}$ in the body during pregnancy can have teratogenic or lethal effects. A deficiency of this element may cause preterm birth, pregnancy-induced hypertension $(\mathrm{PIH})$, low birth weight, preeclampsia, and placental insufficiency. High concentrations of Fe in pregnant women may increase the amount of reactive oxygen species (ROS,) lead to hemochromatosis and prelabor rupture of membranes. Fe deficiency, in turn, may lead to iron deficiency anaemia (IDA), low birth weight, and preeclampsia. Hypercupremia may lead to Wilson's disease and Fenton's reagent, and may contribute to premature birth, low birth weight, and gestational diabetes. Hypocupremia may lead to hypochromic anemia, intrauterine growth restriction (IUGR), spontaneous delivery, and spontaneous abortion. Large amounts of inorganic Fecan be found in lentils and spinach, while organic Fe is abundant in pork liver. Oysters, beef liver, and cocoa are rich sources of $\mathrm{Cu}$, while calf liver, pumpkin, pork liver, and white beans have high concentrations of $\mathrm{Zn}$.

During pregnancy, the diet should meet the needs of the baby, as well as that of the mother, whose health is closely related to the provision of adequate amounts of essential elements including Fe, $\mathrm{Cu}$, and $\mathrm{Zn}$. Their levels before pregnancy can also be of significance [22]. The study by Caan et al. [23] showed that the Special Supplemental Nutrition Program for Women, Infants, and Children (WIC) initiated 5-7 months before pregnancy resulted in an increase in birth weight by $131 \mathrm{~g}$ and length by $0.3 \mathrm{~cm}$. Providing the right amount of essential elements with a diet or by supplementation can reduce the risk of fetal malformation and preterm birth [24], including multiple pregnancies-associated with a higher risk of perinatal complications [25]. These complications are likely to cause premature birth, miscarriage, hypotrophy of one or both fetuses, preeclampsia, fetal death, or fetal atrophy syndrome [26].

\section{Iron (Fe)}

Iron $(\mathrm{Fe})$ is a microelement necessary for the proper functioning of living organisms. An adult female body contains about $2 \mathrm{~g}$ of $\mathrm{Fe}$ (42 $\mathrm{mg} \mathrm{Fe} / \mathrm{kg}$ body weight, b.w.), mainly in the 
hemoglobin(Hgb; 60\%), in ferritin and hemosiderin in the liver, spleen, and bone marrow, and myoglobin and some enzymes, including catalase, peroxidases, and cytochromes [27].

Fe is involved in many metabolic processes, including oxygen respiration, detoxification of reactive oxygen species (ROS), drugs and xenobiotics, and the synthesis and metabolism of various compounds, such as hormones, myelin, neurotransmitters, nucleic acids, and heme. Fe participates in the transport of molecular oxygen from the lungs to all body tissues and cells [28]. This element takes part in erythropoiesis and immune reactions affecting the humoral and cellular immunity of the body [29-32]. The iron is essential trace elementfor collagen synthesis and the conversion of 25-hydroxyvitamin D into an active form [33]. Fe plays an important role in electron transport [34] and takes part in the regulation of the cell cycle by influencing the expression of certain genes, such as protein kinase $C$, nitric oxide synthase, and cyclin dependent kinase inhibitor1A(p21) [32,35,36].

Iron is supplied to the human body with the food. A balanced diet for men should contain about 1-2 mg Fe per day [37], while women, due to blood loss during menstruation, should intake 4-5 mg per day [38]. During pregnancy, this level should increase from $4 \mathrm{mg}$ in the 1 st trimester to $8 \mathrm{mg}$ in the 2nd trimester, and $15 \mathrm{mg}$ per day in the 3rd trimester [39], due to the increased demand associated with fetal growth, placenta, Hgb formation, and the increase in maternal muscle mass, especially in the 2nd and 3rd trimester of pregnancy [40]. During pregnancy, plasma volume increases by $40-60 \%$ and red cell mass by $18-25 \%$ [41-43]. Hemoglobin concentration decreases to $10.5-11 \mathrm{~g} / \mathrm{dL}$ and the hematocrit value to $30-32 \%[42,44]$. This process, known as hemodilution, usually intensifies between the 17th and 36th weeks of pregnancy [43]. Additionally, it may result in a slightly decreased vitamin $B_{12}$ concentration (in about 10-28\% of women) [45] and a slight decrease in platelet count [46]. It is also worth noting in that during this time (i.e., 17-36 weeks) the number of white blood cells increases by about $20 \%$ due to increased hormonal activity (e.g., glucocorticosteroids) and cytokine synthesis (an increase in granulocyte-macrophage colony-stimulating factor) [47]. The World Health Organization (WHO) and the Centers for Disease Control and Prevention (CDC) define anemia in the 1st and 3rd trimesters as $\mathrm{Hgb}$ concentrations below $11.0 \mathrm{~g} / \mathrm{dL}$ and hematocrit below $33 \%$. In the 2nd trimester the values are lower, $10.5 \mathrm{~g} / \mathrm{dL}$ and $32 \%$, respectively $[48,49]$. Large amounts of inorganic $\mathrm{Fe}\left(\right.$ non-heme $\left.\mathrm{Fe}-\mathrm{Fe}^{3+}\right)$ can be found in lentils $(8.6 \mathrm{mg} / 100 \mathrm{~g})$, spinach $(3.1 \mathrm{mg} / 100 \mathrm{~g})$, and broccoli $(1.1 \mathrm{mg} / 100 \mathrm{~g})$ [50]. In contrast, organic $\mathrm{Fe}\left(\right.$ heme $\left.\mathrm{Fe}-\mathrm{Fe}^{2+}\right)$ is mainly found in meat, such as pork liver $(19 \mathrm{mg} / 100 \mathrm{~g})$ and beef $(3.1 \mathrm{mg} / 100 \mathrm{~g})$ [50]. The assimilability of $\mathrm{Fe}^{3+}$ is about $10 \%$ and $\mathrm{Fe}^{2+}$ up to $50 \%$ [51].

Human food most often contains $\mathrm{Fe}^{3+}$, reduced by ferrireductase to $\mathrm{Fe}^{2+}$ in the intestinal lumen [52]. $\mathrm{Fe}^{2+}$ absorption is based on the principle of active transport with a divalent metal transporter (DMT-1) in the apical membrane of the duodenum and the upper part of the small intestine [53,54]. The divalent metal transporter 1 (DMT1) is a non-selective transporter of bivalent metal ions, including iron, zinc, copper, manganese, cobalt, and cadmium, whose transport through the membrane occurs via proton-coupled divalent metal ion transporters [55,56]. Fe levels may also be influenced by the expression of intestinal copper transporting P-type ATPases copper-transporting ATPase $\alpha$ (ATP7A), which indirecly impairs Fe absorption by affecting the expression of Fe transporters [57]. Some researchers suggest a separate mechanism for the absorption of heme Fe which involves heme carrier protein (HCP1), where $\mathrm{Fe}^{2+}$ is transported through the apical membrane of the small intestine to enter the enterocytes, and then binds to apoferritin to form ferritin, a compound used to store $\mathrm{Fe}^{2+}[58,59]$. However, not all researchers agree that HCP1 plays this role [60]. For example, a study by Qiu et al. [61] confirms the thesis that patients with a mutation in the gene encoding HCP1/PCFT have a folate deficiency, with Fe metabolism intact. This shows that mechanism of heme absorption via the intestines is still undefined [60]. The surplus $\mathrm{Fe}^{2+}$ in the enterocytes is transported to the bloodstream by ferroportin (IREG1) and reoxidized to $\mathrm{Fe}^{3+}$ by hephaestin and ceruloplasmin, then immediately bound to the major iron-binding plasma proteinapotransferrin to form transferrin [62,63]. In a study on zebrafish (Danio rerio), Donovan [64] demonstrated that IREG-1 on the surface of placental syncytiotrophoblasts is involved in the transport of Fe from the mother to the fetus. The main protein transporting $\mathrm{Fe}^{3+}$ to cells is transferrin [65]. Equally important 
in Fe turnover is lactoferrin found in breast milk-a source of $\mathrm{Fe}^{3+}$ for newborns and infants [66]. The assimilability of Fe from lactoferrin is about 50\%, while the assimilability of Fe from cow's milk is only about 5\% [29]. Another important source of Fe in the body are macrophages, which recover $\mathrm{Fe}^{2+}$ from erythrocytes [67]. Macrophagesdegrade $\mathrm{Hgb}$, resulting in the release of $\mathrm{Fe}^{2+}$, which is then transported by the transmembrane ferroportin transporter (FPN1) and oxidized by ceruloplasmin to $\mathrm{Fe}^{+}$, to finally bind to transferrin [68]. The whole process is controlled by hepcidin, a peptide synthesized in hepatocytes, which regulates both the amount of Fe absorbed by enterocytes and $\mathrm{Fe}^{2+}$ released by macrophages $[69,70]$.

The bioavailability of Fe in the bloodstream affects the absorption of Fe in the placenta and increases with gestational age [71]. It is likely that the Fe balance between the woman and the fetus is controlled by hepcidin [72]. Thanks to transferrin receptor 1 (TFR 1), Fe combined with transferrin can be transferred to placental syncytiotrophoblasts from the bloodstream [73-75]. Bastin et al. [76] showed the expression of TFR 1 on the apical maternal-facing membrane and, additionally, the expression of ferroportin (FPN) which was localized on the basal fetal-facing membrane. This is the direction that suggests the transport of Fe from mother to fetus. Moreover, the authors noted that ferritin was strongly expressed in the stroma fetal tissue, which suggests iron storage. In the next stage, $\mathrm{Fe}^{3+}$ is reduced to $\mathrm{Fe}^{2+}$ by ferrireductases STEAP 3 and STEAP 4 [77]. Subsequently, the transport of Fe from the endosome, through the basale membrane to the fetus, takes place via DMT-1 [78] and/or ZIP 8 and ZIP 14 [79]. However, Gunshin et al. [80] challenged the theory of DMT-1 involvement in the transport of Fe in the placenta. In their study, the mouse gene DMT-1 was inactivated, but this did not prevent the birth of live offspring and confirmed the effective transfer of Fe through the placenta. Therefore, ZIP 8 and 14 are more important than DMT-1, but current reports are not conclusive for humans in this case $[79,81]$. The second interesting source of Fe supply to the fetus may be ferritin, heme, and non-transferrin-bound iron (NTBI), but unfortunately at this point it has not been confirmed by research. The entire mechanism described in this paragraph is not fully understood and we need considerably more research on how exactly the placenta delivers Fe to the fetus [82,83].

Small amounts of Fe are excreted from the body with urine, saliva, sweat, and also as a result of physiological blood loss in the digestive tract [84-86]. In women, epithelial exfoliation and blood loss during menstruation cause a loss of about $1 \mathrm{mg}$ of Fe [38]. To compensate for this loss, a similar amount of Fe is absorbed from the gastrointestinal tract [87]. During pregnancy, intestinal absorption of Fe in the 2nd and 3rd trimester increases by about $3 \mathrm{mg}$ compared to the physiological state [88]. The high loss of Fe from the body is compensated by reserves stored in hepatocytes or macrophages [89]. The correct Fe concentration in blood should be $80-130 \mu \mathrm{g} / \mathrm{L}$ and remains in dynamic equilibrium with the concentration of this element in erythrocytes, bone marrow, and in its free form [27].

Fe deficiency may occur as a result of a low Fe supply [90], increased blood loss [91], intravascular hemolysis with hemoglobinuria occurring in malaria [92], Ancylostoma duodenale [93], Fe absorption disorders from the gastrointestinal tract in the course of e.g., Helicobacter pylori infections, inflammatory bowel diseases, coeliac disease [94], congenital or acquired transferrin deficiency [95], cancer [96], and increased demand for Fe, e.g., during pregnancy [97]. The risk of Fe deficiency is high among women during pregnancy and lactation, children and adolescents during intensive growth, vegetarians, and in the elderly [98]. In addition, poisoning or oversupply of certain heavy metals, including lead, manganese or cobalt may also cause Fe deficiency. [99]. Fe homeostasis is particularly vulnerable to $\mathrm{Pb}$ due to its ability to bind to DMT1, which results in the secondary inhibition of Fe absorption [100].

In a study on laboratory animals (C57BL/6 mice), Hubbard et al. [101] found that removal of Fe from the diet reduced the birth weight of the offspring and increased the risk of stillbirth. Woodman et al. [102], in a study on Sprague-Dawley rats, evaluated mitochondrial function and ROS generation in animals totally or partially deprived of Fe in their diet. The authors showed an increase in the number of mitochondria in male kidneys. Additionally, they found an increase in cytosolic superoxide inmale kidneys and liver and in female kidneys. The results suggested that male fetuses were more susceptible to mitochondrial disorders and oxidative stress than female fetuses. 
At the beginning of pregnancy, a woman's body uses tissue reserves of Fe (e.g., from hepatocytes) [103]. In laboratory tests, the only indicator is a decrease in serum ferritin concentration at normal serum Fe levels [104]. Then, as a result of increased hematopoiesis and the development of the fetus and placenta, the Fe reserves in the mother's body are exhausted [105]. This results in hypochromic microcytic anemia, especially in the 2 nd and 3rd trimester, which may give adverse symptoms of organ and tissue dysfunction [106]. Premature birth or a low weight birth may occur [107], as well as myocardial hypoxia (e.g., tachycardia) [108], cerebral hypoxia (e.g., weakness, drowsiness, headaches, and dizziness) [109-111], immunosuppression [111], and appetite disorders (e.g., eating chalk) [112]. The prevalence of anemia in pregnant women ranges from $17 \%$ to $31 \%$ in Europe and North America, 53-61\% in Africa, and 44-53\% in Southeast Asia [113]. Milman et al. [114] found that the prevalence of iron deficiency (ID) and iron deficiency anemia (IDA) in pregnant women from Europe is $10-32 \%$ and $2-5 \%$, respectively, and the lack of Fe supplementation during pregnancy increased the prevalence. Only $20-35 \%$ of women of childbearing age did not require additional Fe supplementation.

Insufficient supply of Fe can cause disorders in oxygen transport and consequently lead to anemia [100]. It is particularly dangerous for women of reproductive age due to blood loss during menstruation and also during pregnancy [115]. Fe deficiency may cause preeclampsia and premature fetal membrane rupture in pregnant women [116], and also lead to a decrease in the child's vital signs $[117,118]$. The meta-analysis of Figueiredo et al. [119] proved that maternal anaemia was associated with a higher risk of low birth weight. Pregnant women, especially those with multiple pregnancies, should monitor Fe levels from the beginning of the pregnancy. Low Fe concentration at the beginning of pregnancy significantly correlates with the occurrence of anemia in the last trimester of pregnancy [120]. Therefore, it is recommended to supplement pregnant women's daily diet with $27 \mathrm{mg}$ of Fe per day, and with as much as $60 \mathrm{mg}$ if they are diagnosed with anemia [121,122].

Fe-containing preparations have been found to have a positive effect on the course of pregnancy and in the perinatal period. The supplementation of pregnant women with this micronutrient may increase the bodyweight of newborns by $200 \mathrm{~g}$ on average [123]. On the other hand, excessive Fe supplementation may lead to an increase in ROS formation, which in turn leads to tissue and organ damage [124]. Peña-Rosas et al. [125] evaluated the effect of Fe supplementation in pregnant and perinatal women and noted that daily Fe supplementation had a beneficial effect on the course of pregnancy, reducing the risk of low birth weight of the newborn, and preventing the occurrence of anemia in women. Abioye et al. [126] studied the effect of taking Fe supplementation in a group of pregnant women with a deficiency of this element, assessing the value of hematological parameters in patients before and after birth. The authors demonstrated a significant increase in the levels of ferritin, hepcidin, and Hgb, and a decreased level of soluble transferrin receptor (sTfR). The increase in $\mathrm{Hgb}$ concentration in the mothers also resulted in a reduced risk of newborn death. Similar results concerning an increase in Hgb concentration and a decrease of anemia in women were described by Zhao et al. [127]. Peña-Rosas et al. [128] found that pregnant women taking daily preparations containing Fe were less at risk of adverse events and anemia during pregnancy than women who supplemented this element irregularly. In contrast to other researchers, Ziaeii et al. [129] showed that there was no significant relationship between the dosage of Fe-containing supplements and ferritin concentration in pregnant women. Ali et al. [130] also studied the effects of different levels of Fe supplementation in women pregnant with twins from 12 to 36 weeks of pregnancy. One group of women received $27 \mathrm{mg}$ of Fe daily and the other group $54 \mathrm{mg}$. In both groups, $\mathrm{Hgb}$ and hematocrit (Hct) levels were normal throughout the study period, and in only one group was the mean ferritin level higher. The authors concluded that a daily intake of $27 \mathrm{mg} F$ is as effective as a higher dose of Fe. The higher level of in Fe supply did not affect $\mathrm{Hgb}$ and Hct levels, but it did increase the incidence of side effects (nausea or vomiting). In the study by Shinar et al. [131] on 172 women pregnant with twins with IDA, divided into two groups receiving 34 and $68 \mathrm{mg}$ of Fe sulfate, showed that higher doses of Fe caused higher Hgb values in the examined women. 
Acute poisoning was observed as a result of an overdose of Fe from a pharmaceutical preparation [132]. If the transferrin potential is exhausted or exceeds $85 \%$ in the blood, non-transferrin-related Fe (NTBI) may occur, increasing the risk of intraocular and cardiac Fe accumulation [133]. NTBI initially appears in the bloodstream and then is transported to the interstitial cells via a transferrin-independent mechanism [134]. It was initially assumed that DMT1 transporter is responsible for the transfer of NTBI to the liver and then its removal, but a study on DMT1-negative mice showed they were not protected against the accumulation of Fe in the liver. Therefore, another mechanism was proposed, consisting in the ability of Zip14 to uptake NTBI [135]. Two types of hemochromatosis have been identified: primary (hereditary) and secondary (acquired, due to excessive accumulation of Fe in the body) [136]. As a result of excessive Fe accumulation in organs, such as the heart, liver, and endocrine glands, their function is impaired, producing cardiomyopathy, cirrhosis, or insulin-dependent diabetes $[136,137]$. In case of pregnancy, the liver metabolism error described above had a negative effect on the fetus's Fe balance, which was emphasized in the study by Silver et al. [138]. The placenta acquired excessive amounts of Fe and passed them to the fetus, although the authors could not identify any underlying mechanism of this effect, indicating the necessity for further research on the metabolism and kinetics of Fe transport to the fetus.

A high accumulation of Fe results in the reduced absorption of other essential elements including zinc, copper, molybdenum, chromium, manganese, and magnesium, and the production of ROS [139]. Oxidative stress is particularly dangerous for pregnant women, who may suffer damage to the placental tissue and consequently a premature birth [124]. Oxidative stress leads to faster aging of the cells, which gives a signal to the uterus to contract, resulting in premature birth. This process can also lead to the rupture of the fetal membrane [140].

\section{Copper $(\mathrm{Cu})$}

Copper is an essential micronutrient. It has been estimated that the amount of this element in an adult human body ranges from 50 to $120 \mathrm{mg}$ [141]. The highest concentrations of $\mathrm{Cu}$ were found in the brain and the liver [142]. Cu is involved in the formation and metabolism of bone tissue and participation in oxidation-reduction reactions as a coenzyme, a regulator of Fe metabolism and transport, as well as collagen metabolism $[122,143]$. Cu participates in the metabolism of fatty acids, in RNA synthesis, supports the absorption of Fe in the gastrointestinal tract, and participates in the synthesis of myelin $[144,145]$. Cu also participates in the synthesis of melanin and-as a component of tyrosinase-is involved in the conversion of tyrosine to melanin [27].

The copper is delivered with the food. The greatest source of this element is oysters $(44,996 \mu \mathrm{g} / 100 \mathrm{~g})$, beef liver $(6434 \mu \mathrm{g} / 100 \mathrm{~g})$, cocoa $(5000 \mu \mathrm{g} / 100 \mathrm{~g})$, sunflower seeds $(1770 \mu \mathrm{g} / 100 \mathrm{~g})$ [146]. The daily supply of $\mathrm{Cu}$ should be $0.9-1.3 \mathrm{mg}$ per day, although it is mostly consumed in larger amounts-about $2 \mathrm{mg}$ per day [147]. During pregnancy, the demand for $\mathrm{Cu}$ increases to $1 \mathrm{mg} /$ day [122]. Cu homeostasis is determined by the balance between intestinal absorption and biliary secretion [148]. About $50-70 \%$ of $\mathrm{Cu}$ from food is absorbed in the duodenum and upper sections of the small intestine, and small amounts in the stomach $[143,149]$. In the stomach, $\mathrm{Cu}^{2+}$ is reduced to $\mathrm{Cu}^{1+}$ and then absorbed into the intestinal endothelium [150]. Uptake, intracellular transport, and removal of excess $\mathrm{Cu}$ is strictly regulated and involves specific proteins. Copper is transported to cells via two transmembrane proteins: high affinity copper uptake protein 1 (CTR1) and DMT1 [151-153]. CTR1 is responsible for the transport of $80 \%$ of $\mathrm{Cu}$ and other metals to cells $[154,155]$. It is believed that the Ctr1 mutation may lead to the abnormal functioning of intracellular signaling pathways during embryonic development. Kuo et al. [156] found early embryonic lethality associated with a $\mathrm{Ctr} 1$ null mutation in mice. In cytoplasm, $\mathrm{Cu}$ is complexed mainly with metallothionein (MT). Copper ions serve as cofactors of certain enzymes to which they bind via cytoplasmic copper chaperones. Copper chaperone for superoxide dismutase 1 (CSS) and cyclooxygenase (COX) and synthesis of cytochrome c oxidase (SCO) proteins are responsible for the transport of $\mathrm{Cu}$ to superoxide dismutase type 1 (SOD1) and cytochrome coxidase (CCO), respectively. Antioxidant protein 1 (ATOX1) transports $\mathrm{Cu}$ ions to copper transporting P-type ATPases ATP7A 
and copper-transporting ATPase $\beta$ (ATP7B), which regulate the concentration of $\mathrm{Cu}$ ions in the cell and mediate the incorporation of cations of this element into enzymatic proteins [157]. The lack of ATOX1 results in the accumulation of $\mathrm{Cu}$ and inhibition of its secretion. The role of six-transmembrane epithelial antigen of the prostate (STEAP) and duodenal cytochrome b (Dcytb) in Cu metabolism is poorly understood [153]. In the blood, $\mathrm{Cu}$ occurs in complexes with histidine, threonine, and glutamic acids transported to the liver, kidney, intestines, and other tissues $[143,158]$. The main organ responsible for $\mathrm{Cu}$ metabolism is the liver, which accumulates this element in the prenatal and postnatal period, as well as synthesizing ceruloplasmin and producing bile, which has a high $\mathrm{Cu}$ concentration [122,143-145,148-150,158-162].

$\mathrm{Cu}$ is excreted from the body with urine and feces. Only $2 \%$ of $\mathrm{Cu}^{1+}$ is excreted through the kidneys because in proximal tubules $\mathrm{Cu}$ is mostly reabsorbed by ATP7A proteins and then returned to the bloodstream [163]. In the liver, the excess $\mathrm{Cu}$ is transported via ATP7B and bound with substances contained in the bile and passed to the digestive tract where it is removed with the feces [164,165]. In this way, more than $90 \%$ of the excess $\mathrm{Cu}$ is excreted, and its incorporation into ceruloplasmin prevents reabsorption from the intestines.

The process of transporting $\mathrm{Cu}$ to the placenta from the maternal circulation is probably caused by the copper transport protein 1 (CTR1), as shown by Lee et al. [166], who deprived the mouse of CTR1 and observed teratogenicity or fetal mortality in the uterus. When $\mathrm{Cu}$ is delivered to the placenta, the element is attached to the copper-transporting P-type ATPases (ATP7A or ATP7B) [167]. The ATPases are coordinated with each other as ATP7A is located on the basolateral membrane and is responsible for the excretion of $\mathrm{Cu}$ into the fetal circulation. In contrast, ATP7B is in a perinuclear compartment or the microvillar membrane, releasing excess $\mathrm{Cu}$ into maternal circulation [168]. In contrast, McArdle et al. [169] do not agree with this model of transporting $\mathrm{Cu}$ in the placenta and believe that this mechanism should be further investigated.

$\mathrm{Cu}$ deficiency is rare due to the high availability of this element in food [170]. Cu deficiency may lead to pancytopenia and the occurrence of hypodermic anemia which does not respond to the administration of Fe [171,172], loss of appetite [173], damage to internal organs [174,175], bone deformities [176], reduced reproductive capacity [177], myocardial fibrosis [178,179], and chronic debilitating diarrhea [180]. It may lead to neurological disorders, and hair depigmentation [181,182]. A deficiency of this micronutrient during pregnancy may lead to oxidative stress, which often results in reduced fetal growth [122]. Cu has an important role in the production of collagen and elastin, and an insufficient amount of this element can lead to a reduction in the tensile strength of the fetal membrane, resulting in its interruption and premature birth [183]. On the other hand, excessive administration of $\mathrm{Cu}$ causes vomiting, diarrhea, as well as liver necrosis, acute kidney damage, and-ultimately-death [184,185].

Several diseases related to abnormal Cu metabolism have been described, especially those caused by $\mathrm{Cu}$ deficiency. An example is Menkes disease which is caused by the absence of or defecst in two Cu-transporting ATPases encoded by the ATP7A gene, which affects the absorption of $\mathrm{Cu}$ ions in the gastrointestinal tract [186]. This condition, found in one per 300,000 live birthsin the European population [186], is due to the mutation of the ATP7A gene on the chromosome 3 that causes X-linked recessive disorders [187]. It affects almost exclusively men, with women considered to be only carriers of the mutation, except a few isolated female cases reported in literature [188]. Menkes disease is characterized by significant physical and mental impairment of patients and death in early childhood [187]. In rare cases, the activity of ATP7A protein is partially preserved and the symptoms milder (occipital Horn syndrome), with patients living as long as 50 [171]. The mutation in the ATP7A gene does not necessarily lead to Menkes disease; it has also been described in patients suffering from hereditary motor neuropathy which results in the weakness of the upper limbs that progresses with age [189]. Another disease leading to the disorder of $\mathrm{Cu}$ metabolism is Huppke-Brendel syndrome, resulting from the mutation of the SLC33A1 gene encoding the AT-1 protein, first described in 2012 [190]. People with this syndrome have very low levels of $\mathrm{Cu}$ and ceruloplasmin, and often do not reach the age 
of 6. The symptoms of this disease include psychomotor disability, hypoplasia, and hypomyelination, probably due to the lack of ATP7A protein acetylation. Another disease affecting $\mathrm{Cu}$ homeostasis is MEDNIK syndrome (mental retardation, enteropathy, deafness, ichthyosis, keratoderma), caused by the mutation of the AP1S1 gene located on the long arm of chromosome 7 at position q22 [191]. The patients suffer from mental and motor impairment and deafness; other characteristic symptoms include dermatological changes including excessive keratosis and exfoliation of the epidermis with features of fish scale (lat. ichthyosis) and erythroderma.

Kashaninet al. [192] studied the effects of $\mathrm{Cu}$ on pregnancy. They showed that women who had been supplemented with $1000 \mathrm{mg}$ of $\mathrm{Cu}$ daily from the 17th week of pregnancy experienced reduced depression symptoms in the 2nd and 3rd trimesters of pregnancy compared to the control group. Jankowski et al. [193] demonstrated in an in vitro study on rat embryos that $\mathrm{Cu}$ is essential for early embryonic development. The fetus is sensitive to a lack of $\mathrm{Cu}$, which may lead to irreversible changes in the nervous system [194,195]. Meta-analysis by Lewandowska et al. [196] showed that reduced serum $\mathrm{Cu}$ levels at the beginning of pregnancy were associated with a higher risk of pregnancy-induced hypertension. Prohaska and Brokate [197] showed that a correct amount of $\mathrm{Cu}$ in the body has a protective effect during pregnancy. Vukelići et al. [198] found that in women with normal fetal development, $\mathrm{Cu}$ levels were significantly higher than in women with fetal developmental disorders. Another study also showed that $\mathrm{Cu}$ protects against spontaneous miscarriages [16]. However, elevated $\mathrm{Cu}$ levels in the first trimester of pregnancy may lead to later pregnancy complications, including spontaneous miscarriages [199]. Li et al. [200] concluded that too much Cu can increase the incidence of gestational diabetes, which - if untreated — can lead to macrosomia, intrauterine hypotrophy, birth defects, and miscarriages.

An excess of $\mathrm{Cu}$ is harmful but rare [201]. It results in the formation of free radicals that damage cell membranes and proteins in the body (the so-named Fenton Reaction) [202]. Excess Cu has been observed in the course of Wilson's disease (WD) as a result of abnormal cellular transport [203]. In pregnant women with WD, it is important to take early treatment to prevent spontaneous miscarriages [204,205]. In pregnant women, $\mathrm{Cu}$ levels may be elevated due to increased levels of $\mathrm{Cu}$-bearing proteins [206] and may cause premature births and low birth weight compared to pregnancies with normal $\mathrm{Cu}$ levels [122].

\section{Zinc (Zn)}

As an essential trace element (micronutrient), $\mathrm{Zn}$ has several important roles in human bodies, and after Fe, it is the second most abundant trace element [207]. The total $\mathrm{Zn}$ content in the human body is $2-4 \mathrm{~g}$, with a plasma concentration of $12-16 \mu \mathrm{M} / \mathrm{L}$ [208-210]. In cells, $\mathrm{Zn}$ is present as a divalent ion $\left(\mathrm{Zn}^{2+}\right)$ [211]. The highest $\mathrm{Zn}$ concentrations have been found in skeletal muscle $(60 \%)$, bones $(30 \%)$, liver (5\%), and skin (5\%) [212].

$\mathrm{Zn}$ is a co-factor of more than 300 enzymes that regulate a variety of cellular processes and cellular signaling [213]. It is responsible for the DNA-binding ability of many transcription factors through the unique ability to form molecules known as $\mathrm{Zn}$ finger (Znf) proteins [214]. Zn is essential for cell division, differentiation, and the development of organs, such as the kidneys and heart [215]. It is required for normal testicular development [216]. Zn regulates reproduction, fetal development, membrane stability, digestion, wound healing, and homeostasis of the central nervous system [217-219]. As a cofactor for the enzymes, Zn participates in bone mineralization and collagen structure development of the bone [220]. Zn influences the function of many hormones, including growth hormone, insulin, testosterone, and gonadotropins [221]. It plays a role in the synthesis, storage, and secretion of insulin. This element is also a component of thymulin, a thymus hormone, essential for maturation and differentiation of $\mathrm{T}$ cells $[222,223]$. Zn participates in the elimination of free peroxide radicals, as part of peroxide dismutase (Zn-SOD) [224]. It inhibits the oxidation of unsaturated fatty acids [225], regulates the concentration of vitamin A in plasma [226], and acts as an antagonist of cadmium and lead [227].

Recommended daily intake of $\mathrm{Zn}$ depends on several factors such as age, sex, weight, and phytate content of the diet [228]. Food products containing the most $\mathrm{Zn}$ (per $100 \mathrm{~g}$ ) are calf liver (8.4 mg), 
pumpkin $(7.5 \mathrm{mg})$, pork liver $(4.5 \mathrm{mg})$, and white beans $(3.8 \mathrm{mg})$ [159]. Zn is best assimilated from meat products (red meat, fish) than from plant products [229]. The degree of bioavailability of $\mathrm{Zn}$ from food depends on the concentration of $\mathrm{Zn}$ in the body, stress [230,231], functional state of the kidneys [232] and/or liver [233], $\mathrm{pH}$ of the nutrient content [234]. The presence of citric acid [235], a high intake of animal proteins [236], the presence of highly processed products and lactose [237] have a positive influence on the bioavailability of $\mathrm{Zn}$. Negative effects on $\mathrm{Zn}$ absorption are by heavy metals (cadmium and mercury), calcium, $\mathrm{Fe}, \mathrm{Cu}$, oxalates, phosphates, alcohol, folates, and phytates, alkaline drugs, contraceptives, and diuretics [238-241].

Daily Zn supply according to WHO should be $6.5 \mathrm{mg} /$ day for women and $9.4 \mathrm{mg} /$ day for men (both over 19 years of age) [242]. Due to hemodilution and decreased albumin levels, Zn serum concentration declines during pregnancy [243]. Since intestinal absorption is not increased during pregnancy, an additional $\mathrm{Zn}$ requirement for fetal and placental tissues must be covered by increased intake and from maternal tissues. Therfore, daily requirements for $\mathrm{Zn}$ during pregnancy range from 7.3 to $13.3 \mathrm{mg}$ [244]. Zn enters the human body through the digestive and respiratory systems, and skin. $\mathrm{Zn}$ is absorbed by passive diffusion in the intestine by specific zinc transporting proteins [245]. The most important Zn transporters include Zrt-/Irt-like protein (ZIP) zinc transporters and ZnTs (zinc transporters) [246]. The zinc transporter protein-1 (ZnT1)-ZnT10 which decrease cytoplasmic zinc level by zinc export, and Zip (Zip 1-14) which increase cytoplasmic zinc level by zinc import [246]. The ZIP4 transporter can be found in the entire digestive tract and is responsible for $\mathrm{Zn}$ transport from the apical membrane into enterocytes [247]. Additionally, similar to Cu, DMT1 transporter may help in the absorption of $\mathrm{Zn}$, by transporting $\mathrm{Zn}$ from the intestinal lumen into the enterocytes [248].

The average absorption of $\mathrm{Zn}$ from food is $33 \%$ [249]. $\mathrm{Zn}^{2+}$ ions in the plasma are transported to the cells mainly as complexes with albumin (84\%), alpha-2-macroglobulin (15\%), and amino acids $(1 \%)[250,251]$. They also form complexes with cysteine and histidine [252,253]. Metallothioneins (MT) play an important role in cellular transport [254]. These low-molecular proteins, rich in cysteine residues, are located in the extra- and intracellular environment [255]. Their intracellular pool acts as a reservoir of important heavy metals, including $\mathrm{Zn}$, and participates in the detoxification of ROS, nitrogen, excess heavy metals, and organic compounds [256-259]. Their extracellular pool is responsible for the transport of $\mathrm{Zn}^{2+}$ (and other heavy metals) and organic compounds, and is also a free radical scavenger [256]. One MT molecule is capable of binding seven $\mathrm{Zn}^{2+}$ ions and up to 12 monovalent $\mathrm{Cu}$ ions [260,261]. The intra- and extracellular $\mathrm{Zn}$ concentration is controlled by two families of transporters: ZnT (SLC30-Soluble Carrier 30) and ZIP (SLC39A1-A14) [262,263]. ZIP proteins are responsible for the transport of $\mathrm{Zn}^{2+}$ to the cell cytoplasm [264]. ZnT proteins originate from a large family of Cation Diffusion Facilitator (CDF) proteins and are responsible for transporting $\mathrm{Zn}$ ions from the cytoplasm of the cell to cell organelles or outside the cell [265]. The main organ responsible for the metabolism and systemic $\mathrm{Zn}$ homeostasis is the liver [266]. $\mathrm{Zn}$ is excreted mainly in feces $(90 \%)$ and the rest of $Z n$ is excreted in the urine, sweat, and saliva, and incorporated into hair [267].

The transport of $\mathrm{Zn}$ to the fetus is fully dependent on its concentration in the mother's blood [268]. Its low intake will reduce the expression of $\mathrm{ZnT}$, resulting in less $\mathrm{Zn}$ being transported in the placenta, protecting the mother against $\mathrm{Zn}$ homeostasis disorder. Zinc released from enterocytes into the mother's blood through ZnT1 reaches placental syncytiotrophoblasts using ZIP proteins [269]. In the next step Zn can be intercepted by transporters including ZIP 14 and ZIP 8, ZnT2 and DMT-1 or bind to MT and in this form delivered to the fetus $[81,270,271]$. This mechanism requires further investigation.

A Zn deficiency caused by inadequate dietary intake is a common phenomenon and affects up to two billion people in the world, mainly in developing countries [272,273]. Marginal Zn deficiency is estimated to affect $82 \%$ of pregnant women worldwide [274]. Zn deficiency can be classified as primary or secondary. Primary Zn deficiency may lead to growth retardation, puberty delay, immune deficiency, and the impairment of cognitive function, taste, and smell [275]. Major manifestations of Zn deficiency include growth retardation, testicular and ovarian dysfunction, immune dysfunctions, and cognitive impairment [276]. Maternal Zn deficiency during pregnancy is linked with adverse pregnancy 
outcomes including abortion, preterm delivery, stillbirth, and fetal neural tube defects [277-279]. Secondary Zn deficiency is caused by gastrointestinal diseases, including malabsorption syndrome and Crohn's disease [280]. It may also be caused by heavy hemorrhage, cirrhosis, kidney disease, and alcoholism [281-283].

$\mathrm{Zn}$ takes part in the embryogenesis and formation of the fetus, and so its low level may result in impaired development and affect the final phenotype of the newborn's organs [284,285]. Additionally, during pregnancy, a deficiency may contribute to preterm delivery, pregnancy-induced hypertension, low birth weight, and preeclampsia [286]. Zn deficiency may lead to faulty estrogen function, resulting in uterine spasms, cervical dilation, and amniotic fluid integrity [287]. Zn deficiency is also involved in the synthesis of prostaglandins, as well as collagen synthesis and degradation, and so its absence may result in premature fetal membrane rupture [280]. In laboratory animal studies, Zn deficiency during the early stages of pregnancy is associated with reduced fertility [288] and the increased incidence of nervous system congenital malformations [289]. Zn deficiency in later stages of a pregnancy negatively affects neuronal growth and brain function and synaptogenesis and may be associated postnatally with impaired brain function and behavioral abnormalities [290].

Scientific literature data on the influence of $\mathrm{Zn}$ supplementation on the course of pregnancy and fetal development are divergent. Nossier et al. [291] concluded that Zn intake minimizes the risk of premature birth in women and infections in newborns. A double-blind and randomized controlled study shows that Zn supplementation during pregnancy improves birth length after adjusting for maternal height and pre-pregnancy weight [292]. Wang et al. [293] in a cohort study on 3187 pregnant women from China, concluded that Zn deficiency in the diet of pregnant women increases the risks of low birth weight and small gestational size. Merialdi et al. [294] noted that prenatal supplementation of Zn-deficient mothers may be beneficial to fetal neurobehavioral development. In an earlier study, Merialdi et al. [295] concluded that the fetuses of mothers who received Zn supplementation showed fewer episodes of minimal fetal heart rate variability, increased fetal heart rate range, an increased number of accelerations, an increased number of movement bouts, an increased amount of time spent moving, and an increased number of large movements. Further, Merialdi et al. [296], studying the effect of Zn supplementation of pregnant women on fetal bone growth found that supplementing Zn-deficient mothers with $25 \mathrm{mg}$ Zn/day caused a higher fetal femur diaphysis length. This was caused by this microelement stimulating osteoblast production and inhibiting osteoclast activity.

In a study in laboratory animals (C57B1-6J mice) Wilson et al. [297] proved that the lack of Zn in the diet negatively affected the growth and development of the offspring in the uterus mainly due to impaired placenta development. Additionally, they noted that a lack of $\mathrm{Zn}$ affected the capacity of the heart and organ perfusion. Correct blood pressure in the pregnant woman is essential to properly maintain the growth of the fetus and provide appropriate nutrients [298]. Many studies have shown a slight effect of Zn supplementation or lack of it on maternal and fetal bodies [299-301]. Meta-analysis by Chaffee and King [302] concluded that the additional supply of Zn does not affect fetal morphometric results. Discrepancies in study results may have been caused by a different study area. In developing countries, shortages of Zn occur quite frequently, compared to developed countries, where such a phenomenon is probably related to low social status, as confirmed by Mori et al. [303]. Finally, King [304] concluded that Zn supplementation is essential to counteract the effects of smoking, alcohol abuse, infections, injuries, and impaired gastrointestinal function.

There are not many reports on Zn supplementation in women with multiple pregnancies. Goodnight et al. (2009) concluded that in this group additional supplementation could bring positive benefits [305]. Mahomed et al. [306] noted that 15-44 $\mathrm{mg}$ of Zn supplementation per day was associated with a $14 \%$ reduction in preterm birth. Campbell et al. [307] noted the Zn concentration in plasma in twin pregnancies was similar to that in single pregnancies. It may suggest that the body regulates $\mathrm{Zn}$ deficiency in case of multiple pregnancies without additional supplementation. 
High doses (100-300 mg/d) of Zn disturb many biochemical processes [308]. Excess Zn can manifest itself through nausea, vomiting, abdominal cramps, and diarrhea [309]. According to WHO [310], excess Zn during embryogenesis can be teratogenic or ultimately fatal.

\section{Fe vs. Cu}

Dietary $\mathrm{Fe}$ and $\mathrm{Cu}$ are absorbed in the proximal small intestine [311]. These elements must be reduced before uptake into enterocytes, then both metals are oxidized after export into the interstitial fluids [312]. Chen et al. [313] showed that Cu-deficient C57BL/6J mice had significantly lower hephaestin and ceruloplasmin $(\mathrm{Cp})$ ferroxidase activity. Cu facilitates the absorption and utilization of Fe [314], which takes part in red cell regeneration [315] and bone formation [316].

$\mathrm{Ha}$ et al. [312] proved that with a high supply of $\mathrm{Fe}$, there is a lower $\mathrm{Cu}$ concentration in diseased tissue, and serum $\mathrm{Cu}$ activity decreases. Ha et al. [317] also analyzed the mechanism responsible for the impairment of $\mathrm{Cu}$ absorption by feeding mice with a feed containing an appropriate amount of $\mathrm{Fe}$ and low/suitable/high $\mathrm{Cu}$ levels. The mice showed no disruption in $\mathrm{Cu}$ absorption and utilization in rodents. However, an increased supply of Fe did impair the utilization of $\mathrm{Cu}$ in the body, although the absorption of $\mathrm{Cu}$ was normal. The authors investigated the locations of absorbed $\mathrm{Cu}$ with a radioactive marker, but could not identify most of the absorbed $\mathrm{Cu}$ in any of the tested tissues. They concluded that additional experiments should be performed to investigate the mechanism of distribution, storage, and bioavailability of $\mathrm{Cu}$ under elevated condition of Fe. The $\mathrm{Cu}$ activity affects the transport of $\mathrm{Fe}$ mainly during blood loss. Hephaestin (protein homolog of ceruloplasmin) is not able to make up for this deficiency on its own and the body replaces it with Cp [318]. Additionally, the reduced Cp activity prevents the release of stored Fe from the spleen and liver macrophages [319]. This is probably caused by the reduction or inhibition of Fe oxidation via Cp [320].

Harris [321] confirmed the role of Cp in the metabolism and release of tissue Fe. This study was conducted on a ceruloplasmin genetic defectin proteinsynthesis in patients who were diagnosed with excessive accumulation of $\mathrm{Fe}$ in the brain and pancreas. This resulted in retinal degeneration and diabetes. The patients were given $\mathrm{Cu}$ intravenously which resulted in increased serum Fe concentration. These results confirm a significant influence of $\mathrm{Cu}$ on the release of tissue Fe. Ha et al. [322] showed that $\mathrm{Cu}$ metabolism is impaired when dietary Fe intake is $>10$ times higher than the normal Fe supply established by WHO. Significantly elevated levels of Fe may result in anemia, likely due to a lack of $\mathrm{Cu}$ in the diet [323]. This is because $\mathrm{Cu}$ is a component of cytochrome oxidase, necessary for oxidative phosphorylation, which allows the incorporation of Fe into heme. Additionally, the lack of Cu may shorten the erythrocyte life span [324]. This may be due to the inhibition of superoxide dismutase, which contains $\mathrm{Cu}$, leading to cell membrane damage by ROS. In addition, there is a decrease in $\mathrm{Cu}$ activity, which inhibits peroxide formation [325]. Hepatic Fe overload also causes liver damage, causing hypertriglyceridemia and hypercholesterolemia [326] and elevated Fe levels may lead to fibrosis or cirrhosis of the liver, via a decrease in superoxide dismutase activity [327]. On the other hand, when the supply of $\mathrm{Cu}$ is increased, the absorption of Fe may be impaired due to the affinity of $\mathrm{Cu}$ to transferrin [328]. However, $\mathrm{Cu}$ overload is very rare because there is a difference between Fe and $\mathrm{Cu}$ in the final metabolism of both elements. $\mathrm{Cu}$ is removed from the body with bile, and there is no mechanism of removing excess Fe.

Sebio et al. [329] concluded that elevated concentrations of $\mathrm{Fe}$ or $\mathrm{Cu}$ in the body cause brain damage due to oxidative stress. Lan et al. [330] found that the accumulation of $\mathrm{Fe}, \mathrm{Cu}$, and cobalt in the brain causes a decrease in glutathione, which is responsible for oxidative protection of neurons. In rats, Fe supplementation lowers the level and absorption of $\mathrm{Cu}$. In patients who received $3 \mathrm{mg}$ of $\mathrm{Cu}$ from 100 or $400 \mathrm{mg}$ of Fe in the form of Fe gluconate, no effect of Fe on $\mathrm{Cu}$ absorption has been demonstrated [331].

The study by Christian et al. [332] on 235 pregnant women showed no negative effect between $\mathrm{Zn}$ and Fe when these elements were administered at a 2:1 ratio. The additional effect of supplementation with these elements was shown by Saak [333] carried out in Ghana on 354 pregnant women given 
a dose of $40 \mathrm{mg}$ of Fe and $\mathrm{Zn}-\mathrm{an}$ increase in $\mathrm{HgB}$ and ferritin values was reported. Although the results of that study suggest a beneficial effect of such a supplementation model, it was effective only for women with Fe deficiency. This was also confirmed in the subsequent study by Saaka et al. [334]. Harvey et al. [335] estimated that even taking $100 \mathrm{mg}$ of Fe with a meal does not affect $\mathrm{Zn}$ metabolism. The authors suggest that $\mathrm{Zn}$ status is maintained after the effective absorption of $\mathrm{Zn}$ from food meals. In the opposite situation, when $\mathrm{Zn}$ was supplemented in a diet, it also did not affect the balance of Fe [336]. However, in the study by $\mathrm{O}^{\prime}$ Brien et al. [337] daily Fe supplementation (60 mg) significantly reduced the absorption of $\mathrm{Zn}$ and only the inclusion of $15 \mathrm{mg} \mathrm{Zn}$ supplementation in the diet of these women reduced this adverse effect of Fe. The authors also noted the need for additional studies in this direction and the establishment of the mechanism that causes such interaction.

\section{Fe vs. Zn}

Zn and Fe interact competitively during intestinal absorption [338]. In a study on animals, Bodiga and Krishnapillai [339] found that the interactions between Fe and Zn during absorption in Fe- and Zn-deficient rats are mutually antagonistic. The competition of Fe and Zn for metaltransporter1 (DMT-1) at the site of absorption results in reduced uptake of these elements during concurrent administration [340]. This was confirmed in a study by Espinoza et al. [56] in which DMT-1 was involved in the active transportof $\mathrm{Fe}, \mathrm{Cu}$, and $\mathrm{Zn}$, although $\mathrm{Zn}$ showed a different relative capacity. Kordas and Stoltzfus [341] showed that althoughFedoes seem to reduce the absorption ofZn, DMT-1 is an unlikely site for this absorptive antagonism because Znis not transported by DMT-1. Zrt- and Irt-like protein-14 (Zip14) is a transmembrane metal iron transporter that is abundantly expressed in the liver, heart, and pancreas [342].

It was found that a 1:1 mass ratio of $\mathrm{Fe} / \mathrm{Zn}$ in the diet causes a slight inhibition of $\mathrm{Zn}$ absorption, whereas when the Fe/Zn ratio is higher, 2:1 or 3:1, the absorption of $\mathrm{Zn}$ is limited. It has been noted that the intake of heme Fe together with inorganic $\mathrm{Zn}$ in the appropriate ratio does not impair the absorption of Zn. Organic Zn does not affect the absorption of Fe [343,344].

Pregnant women have an increased demand for $\mathrm{Zn}$ and Fe [345]. The administration of Fe at more than $100 \mathrm{mg} /$ day to pregnant women resulted in a reduction in serum $\mathrm{Zn}$ compared to the women who were given less than $100 \mathrm{mg}$ of Fe [346]. Women in the first trimester of pregnancy who additionally received multivitamin preparations containing $60-65 \mathrm{mg}$ of Fe showed a reduction in $\mathrm{Zn}$ absorption compared to women receiving less than $30 \mathrm{mg} \mathrm{Fe} /$ day [347]. Ziaei et al. [348] estimated that $\mathrm{HgB}$ greater than $13.2 \mathrm{~g} / \mathrm{dL}$ in pregnant women reduces serum $\mathrm{Zn}$ levels. Andersen et al. [349] suggested that $\mathrm{Cu}$ deficiency has not only a direct effect on the concentration of $\mathrm{Fe}$, but also an indirect effect through regulation of Fe transporters, which, inter alia, affects the delivery of Fe to the fetus. On the other hand, Gambling et al. [350] suggests that there is no connection between Fe and $\mathrm{Cu}$ in their research. Additionally, Shidfar et al. [351] reports that Fe supplementation does not have a significant effect on $\mathrm{Cu}$ levels in the body.

Donangelo et al. [352] examined adult women ( $n=23$; aged 20-28 years), non-anemic but with low Festores. The authors investigated the effect of Fesupplementation (100 mg Fe/day) or Znsupplementation ( $22 \mathrm{mg} \mathrm{Zn/day)} \mathrm{for} 6$ weeks. They found that theuse ofFe supplements in those womenimprovedFeindices with no effect onZnstatus. However, modestZn supplementation improvedZnindices, appeared to induce a cellularFedeficiency and, possibly, further reducedFestatus. In the study by De Brito et al. [353], healthy children of both sexes, aged 8-9 years $(n=15)$, were given a placebo (control group) or $10 \mathrm{mg} \mathrm{Zn/day} \mathrm{(experimental} \mathrm{group)} \mathrm{for} 3$ months. The researchers showed that the decrease in serum Fe was likely due to the effects of chronic $\mathrm{Zn}$ administration. The supplementation did not influence levels of $\mathrm{Hgb}$, mean corpuscular volume, ferritin, transferrin, transferrin saturation, ceruloplasmin, or total protein. Similarly, in a study by Antunes et al. [354] on the acute and chronic effects of $\mathrm{Zn}$ on the serum Fe profile of children aged 6-9 years, there was a decrease in Fe levels due to $\mathrm{Zn}$ supplementation, but no negative effect of $\mathrm{Zn}$ on hematocrit and 
Hgb levels. Wieringa et al. [355] confirmed the positive effect of Fe and Zn supplementation in the prevention of anemia and Zn deficiency.

Holmes et al. [356] studied the effects of multiple micronutrient (MMN) supplementation (15 mg $\mathrm{Zn}, 65 \mathrm{mg} \mathrm{Se}, 2 \mathrm{mg} \mathrm{Cu}$ ) with or without Fe on serum $\mathrm{Zn}$, Se, and $\mathrm{Cu}$ concentrations in women from Cambodia. Predominantly anemic nonpregnant women (aged 18-45) received daily $60 \mathrm{mg}$ of $\mathrm{Fe}$ (I group); MMN, but no Fe (II group); $60 \mathrm{mg}$ Fe plus MMN (III group); or a placebo (IV group). It was found that $60 \mathrm{mg}$ Fe and the daily MMN formulation may be interfering with the absorption and/or metabolism of supplemental $\mathrm{Zn}$. However, patients took the supplement together with food which was not controlled, and so it is possible that $\mathrm{Zn}$ competed for metabolic transporters not only with $\mathrm{Fe}$ and minerals contained in the MMN complex but also with elements from the diet. Troost et al. [331] noted that oral Fe therapy may impair $\mathrm{Zn}$ absorption. A significant decrease in $\mathrm{Zn}$ absorption was observed with 100 and $400 \mathrm{mg}$ of Fe administered in aqueous solution. Unfortunately, that study was limited to a very small group of patients $(n=11)$.

Nguyen et al. [357] conducted a randomized control study on women $(n=459)$ from Guatemala where they received for 12 weeks: (i) weekly $120 \mathrm{mg}$ Fe with $30 \mathrm{mg}$ Zn, (ii) weekly $120 \mathrm{mg}$ Fe, (iii) daily $60 \mathrm{mg}$ Fe with $15 \mathrm{mg} \mathrm{Zn}$, and (iv) daily $60 \mathrm{mg}$ Fe. The combined Fe-Zn supplementation was as effective as Fe alone in improving Fe status, but not effective in $\mathrm{Zn}$ status. This may be because $\mathrm{Zn}$ and Fe compete with each other only when given in aqueous solution, and if supplementation takes place in the form of a solid meal, such an effect is not recorded, although studies are inconclusive in this case [241,358].

\section{Cu vs. Zn}

The high concentration of $\mathrm{Zn}$ in the body caused by the supplementation of this element leads to an increase in the production of metallothionein in the intestinal cells [257]. Cu accumulates in enterocytes due to its high affinity for metallothionein, displacing Zn [359]. As a result of exfoliation of enterocytes in the gastrointestinal tract, $\mathrm{Cu}$ concentration is reduced, which may lead to Cu deficiency [360]. A study by Sutton et al. [361] showed that cytopenia in patients can be caused by a high $\mathrm{Zn}$ concentration in the body combined with $\mathrm{Cu}$ deficiency, and $\mathrm{Cu}$ supplementation leads to a reversal of hematologic levels. According to Prasad et al. [362], increased Zn concentration may be caused by improperly fitting dentures, resulting in increased use of dental adhesive, which contains high levels of $\mathrm{Zn}$. Excess $\mathrm{Cu}$ can lead to both anemia and neutropenia as a result of the mechanisms in which $\mathrm{Cu}$ participates.

Deur et al. [363] concluded that in the case of anemia, Cu deficiency may affect Fe metabolism, including inhibition of $\mathrm{Fe}$ absorption from the gastrointestinal tract and shortening of red blood cell life. In the case of neutropenia, on the other hand, an abnormal synthesis of progenitor cells and abnormal maturation and release of neutrophils into the bloodstream occur. Moreover, the removal of granulocytes containing a low $\mathrm{Cu}$ concentration is increased [364]. Zn concentration in the body influences SOD activity and $\mathrm{Cu}$ level [365]. Extracellular superoxide dismutase and $\mathrm{Cu} / \mathrm{Zn}$ superoxide dismutase react differently to $\mathrm{Zn}$ levels in the body. The extracellular SOD activity increases in response to an increase in $\mathrm{Zn}$ levels, as opposed to SOD Cu/Zn whose activity decreases [366].

$\mathrm{Zn}$ is used to treat Wilson's disease, a condition that leads to an excessive accumulation of $\mathrm{Cu}$ in the liver [367,368], as $\mathrm{Zn}$ supplementation may reduce $\mathrm{Cu}$ concentration in the body [344]. Although $\mathrm{Zn}$ therapy is often insufficient, it plays an important role as a second-line treatment, supplementing the use of trientine or penicillamine [369]. Sometimes, $\mathrm{Zn}$ monotherapy is effective and has therapeutic effects, especially in the neurological Wilson's disease [370]. Malik et al. [371] reported positive effects of $\mathrm{Zn}$ supplementation during pregnancy in WD patients. Optimized doses of $\mathrm{Zn}$ have helped to carry out the pregnancy. However, the authors emphasize that pregnancy in these patients has a high risk of preeclampsia. In the case of acrodermatitis enteropathica (AE) patients in Sandström et al. [241] the status of $\mathrm{Zn}$ and $\mathrm{Cu}$ was measured in response to 1000 and $525 \mu \mathrm{M} / \mathrm{d}$ supplementation. High doses of $\mathrm{Zn}$ supplementation were found to decrease $\mathrm{Cu}$ absorption and during the dose correction the concentration of $\mathrm{Cu}$ was normalised. The authors argue that the primary lesion in AE is a cellular 
defect in Zn metabolism and not a $\mathrm{Zn}$ absorption disorder. Moreover, they point out that in AE it is important to control $\mathrm{Zn}$ and $\mathrm{Cu}$ concentration due to teratogenic effects of $\mathrm{Cu}$ deficiency or excess.

The antagonistic action of $\mathrm{Zn}$ and $\mathrm{Cu}$ has been the subject of many studies. Wu et al. [372] investigated the effects of dietary $\mathrm{Cu}$ and $\mathrm{Zn}$ on apparent mineral retention and serum biochemical indicators in young male mink on a corn-fishmeal based diet. It was observed that moderately high $\mathrm{Cu}$ in the diet increased $\mathrm{Cu}$ retention, but did not reduce $\mathrm{Zn}$ absorption, while moderately high $\mathrm{Zn}$ in the diet reduced plasma $\mathrm{Cu}$ levels.

Eckert et al. [373] showed that the concentration of $\mathrm{Zn}$ in the liver does not change after the administration of $\mathrm{Cu}$ in the diet, which suggests no interaction between these elements. However, Du et al. [374] observed that the relationship between $\mathrm{Zn}$ and $\mathrm{Cu}$ depends on the form of $\mathrm{Cu}$ administration. Complexes of $\mathrm{Cu}$ with protein or lysine caused an increase in the liver concentration of $\mathrm{Zn}$ compared to the administration of $\mathrm{Cu}$ in the form of inorganic salts, which did not induce any changes in $\mathrm{Zn}$ levels.

Zetzsche et al. [375] determine the effect ofhighdietaryZn oxide on trace elementaccumulationin various organs in pigs. They found that dietary $\mathrm{Zn}$ supplementation led to $\mathrm{Cu}$ co-accumulationin thekidneysofthe pigs.

A study by Baecker et al. [376] in an animal model investigated the effect of high Cu concentration and $\mathrm{Zn}$ deficiency on the formation of autism spectrum disorder (ASD). Cu supplementation of pregnant female rats caused a significant decrease in $\mathrm{Zn}$ in the brain, above all in the hippocampus. Additionally, the antagonistic action of $\mathrm{Cu}$ against $\mathrm{Zn}$ caused abnormalities in nerve synapses. Those results suggest that $\mathrm{Cu}$ and $\mathrm{Zn}$ homeostasis disturbances in pregnant females may contribute to brain underdevelopment and nerve impulse transmission disorders, which may lead to ASD development. Similar conclusions were reached by Reinstein et al. [377] showing an increased risk of fetal malformations with insufficient supply of $\mathrm{Zn}$ in the diet and with an increase in $\mathrm{Cu}$. Moreover, Kinnamon [378] reported that $\mathrm{Cu}$ and $\mathrm{Zn}$ are competing with each other in the fetus and placenta. The result of this competition is a greater absorption of $\mathrm{Cu}$, which is pushing out $\mathrm{Zn}$. Although, Garg et al. [379] in a study on pregnant women who were supplemented with $\mathrm{Zn}$ did not report hypocupremia. However, the ratio of both elements should be optimized in pregnancy, to improve reproduction results and reduce the chance of spontaneous abortion [16].

\section{Conclusions}

The presented literature review suggests that $\mathrm{Fe}, \mathrm{Cu}$, and $\mathrm{Zn}$ are crucial for the proper course of pregnancy. The results should be approached with caution, but most studies indicate the influence of metals on the parameters of mother and child. Moreover, $\mathrm{Fe}, \mathrm{Cu}$, and $\mathrm{Zn}$ may be promising biomarkers in predicting complications in pregnancy.

Additionally, the results of the researchers show important relationships between $\mathrm{Fe}, \mathrm{Cu}$, and $\mathrm{Zn}$ in the body. An increase or decrease of one element may significantly affect the action of the other two. It is particularly significant to note that the elements do not exhibit antagonistic actions against each other when they are within daily reference values.

$\mathrm{Fe}, \mathrm{Cu}$, and $\mathrm{Zn}$ play a key role in the homeostasis of the body, and any changes in their concentrations can cause interactions that are dangerous to the health of the mother and fetus.

Author Contributions: K.G.: literature search and review, manuscript draft preparation, writing manuscript, and preparation of manuscript revision. S.K.: participation in writing the manuscript. D.K.-B.: writing the manuscript, preparation of manuscript revision, and final acceptance of the manuscript. All authors have read and agreed to the published version of the manuscript.

Funding: This research received no external funding.

Acknowledgments: This study was supported by the statutory budget of the Department of Biology and Medical Parasitology, Pomeranian Medical University.

Conflicts of Interest: The authors declare no conflict of interests. 


\section{References}

1. Choi, R.; Sun, J.; Yoo, H.; Kim, S.; Cho, Y.Y.; Kim, H.J.; Kim, W.K.; Chung, J.H.; Oh, S.; Lee, S.-Y. A Prospective study of serum trace elements in healthy korean pregnant women. Nutrients 2016, 8, 749. [CrossRef] [PubMed]

2. Kot, K.; Kosik-Bogacka, D.; Łanocha-Arendarczyk, N.; Malinowski, W.; Szymański, S.; Mularczyk, M.; Tomska, N.; Rotter, I. Interactions between 14 Elements in the Human Placenta, Fetal Membrane and Umbilical Cord. Int. J. Environ. Res. Public Health 2019, 16, 1615. [CrossRef] [PubMed]

3. Kocyłowski, R.; Lewicka, I.; Grzesiak, M.; Gaj, Z.; Oszukowski, P.; von Kaisenberg, C.; Suliburska, J. Evaluation of Mineral Concentrations in Maternal Serum Before and After Birth and in Newborn Cord Blood Postpartum-Preliminary Study. Biol. Trace Elem. Res. 2018, 182, 217-223. [CrossRef] [PubMed]

4. Wasowicz, W.; Wolkanin, P.; Bednarski, M.; Gromadzinska, J.; Sklodowska, M.; Grzybowska, K. Plasma trace element (Se, $\mathrm{Zn}, \mathrm{Cu})$ concentrations in maternal and umbilical cord blood in Poland. Biol. Trace Elem. Res. 1993, 38, 205-215. [CrossRef]

5. Kovalchuk, L.; Tarkhanova, A.; Tarkhanov, A. The essential and toxic effects of trace elements in the biological tissues of pregnant women and newborn babies (an ecologically unfavourable region). Int. J. Saf. Secur. Eng. 2013, 3, 265-277. [CrossRef]

6. Skalnaya, M.G.; Tinkov, A.A.; Lobanova, Y.N.; Chang, J.S.; Skalny, A.V. Serum levels of copper, iron, and manganese in women with pregnancy, miscarriage, and primary infertility. J. Trace Elem. Med. Biol. 2019, 56, 124-130. [CrossRef]

7. Sabra, S.; Malmqvist, E.; Saborit, A.; Gratacós, E.; Gomez Roig, M.D. Heavy metals exposure levels and their correlation with different clinical forms of fetal growth restriction. PLoS ONE 2017, 12, e0185645. [CrossRef]

8. Mbofung, C.M.F.; Subbarau, V.V. Trace element (Zinc, copper, iron and magnesium) concentrations in human placenta and their relationship to birth weight of babies. Nutr. Res. 1990, 10, 359-366. [CrossRef]

9. Punshon, T.; Li, Z.; Jackson, B.P.; Parks, W.T.; Romano, M.; Conway, D.; Baker, E.R.; Karagas, M.R. Placental metal concentrations in relation to placental growth, efficiency and birth weight. Environ. Int. 2019, 126, 533-542. [CrossRef]

10. Young, S.M.; Gryder, L.K.; David, W.B.; Teng, Y.; Gerstenberger, S.; Benyshek, D.C. Human placenta processed for encapsulation contains modest concentrations of 14 trace minerals and elements. Nutr. Res. 2016, 36, 872-878. [CrossRef]

11. de Angelis, P.; Miller, R.K.; Darrah, T.H.; Katzman, P.J.; Pressman, E.K.; Kent, T.R.; O’Brien, K.O. Elemental content of the placenta: A comparison between two high-risk obstetrical populations, adult women carrying multiples and adolescents carrying singletons. Environ. Res. 2017, 158, 553-565. [CrossRef] [PubMed]

12. Mikelson, C.K.; Troisi, J.; LaLonde, A.; Symes, S.J.K.; Thurston, S.W.; DiRe, L.M.; Adair, C.D.; Miller, R.K.; Richards, S.M. Placental concentrations of essential, toxic, and understudied metals and relationships with birth outcomes in Chattanooga, T.N. Environ. Res. 2019, 168, 118-129. [CrossRef] [PubMed]

13. Rathore, S.; Gupta, A.; Batra, H.S.; Rathore, R. Comparative study of trace elements and serum ceruloplasmin level in normal and pre-eclamptic pregnancies with their cord blood. Biomed. Res. 2010, 22, 209-212.

14. Singh, L.; Agarwal, P.; Anand, M.; Taneja, A. Toxic and essential metals in placenta and its relation with lipid peroxides/glutathione status in pre-term and full-term deliveries. Asian J. Med. Sci. 2015, 7, 34-39. [CrossRef]

15. Upadhyaya, C.; Mishra, S.; Ajmera, P.; Sharma, P. Serum iron, copper and zinc status in maternal and cord blood. Indian J. Clin Biochem. 2004, 19, 48-52. [CrossRef]

16. Thaker, R.; Oza, H.; Shaikh, I.; Kumar, S. Correlation of Copper and Zinc in Spontaneous Abortion. Int. J. Fertil. Steril. 2019, 13, 97-101. [CrossRef]

17. Reddy, Y.S.; Aparna, Y.; Ramalaksmi, B.A.; Kumar, B.D. Lead and trace element levels in placenta, maternal and cord blood: A cross-sectional pilot study. J. Obstet. Gynaecol. Res. 2014, 40, 2184-2190. [CrossRef]

18. Irwinda, R.; Wibowo, N.; Putri, A.S. The Concentration of Micronutrients and Heavy Metals in Maternal Serum, Placenta, and Cord Blood: A Cross-Sectional Study in Preterm Birth. J. Pregnancy 2019, 2019, 5062365. [CrossRef]

19. Sakamoto, M.; Yasutake, A.; Domingo, J.L.; Chan, H.M.; Kubota, M.; Murata, K. Relationships between trace element concentrations in chorionic tissue of placenta and umbilical cord tissue: Potential use as indicators for prenatal exposure. Environ. Int. 2013, 60, 106-111. [CrossRef] 
20. Shen, P.J.; Gong, B.; Xu, F.Y.; Luo, Y. Four trace elements in pregnant women and their relationships with adverse pregnancy outcomes. Eur. Rev. Med. Pharmacol. Sci. 2015, 19, 4690-4697.

21. Awadallah, S.M.; Abu-Elteen, K.H.; Elkarmi, A.Z.; Qaraein, S.H.; Salem, N.M.; Mubarak, M.S. Maternal and cord blood serum levels of zinc, copper, and iron in healthy pregnant Jordanian women. J. Trace Elem. Exp. Med. 2004, 17, 1-8. [CrossRef]

22. King, J.C. Physiology of pregnancy and nutrient metabolism. Am. J. Clin. Nutr. 2000, 71, 1218-1225. [CrossRef] [PubMed]

23. Caan, B.; Horgen, D.M.; Margen, S.; King, J.C.; Jewell, N.P. Benefits associated with WIC supplemental feeding during the interpregnancy interval. Am. J. Clin. Nutr. 1987, 45, 29-41. [CrossRef] [PubMed]

24. McAlpine, J.M.; McKeating, D.R.; Vincze, L.; Vanderlelie, J.J.; Perkins, A.V. essential mineral intake during pregnancy and its association with maternal health and birth outcomes in South East Queensland, Australia. Nutr. Metab. Insights 2019, 12, 1-12. [CrossRef] [PubMed]

25. Szymankiewicz, M. Incidence and mortality of newborns from multiple pregnancies. Perinatol. Neonatol. $i$ Ginekol. 2010, 3, 245-248.

26. Filipecka-Tyczka, D. Medical care for a pregnant woman with a multiple pregnancy. Postępy Nauk Med. 2016, 7, 475-482.

27. Gertig, H.; Przysławski, J. BBromatology: An Outline of Food and Nutrition Science; Wydawnictwo Lekarskie PZWL: Warsaw, Poland, 2007.

28. Camaschella, C. Iron-deficiency anemia. N. Engl. J. Med. 2015, 372, 1832-1843. [CrossRef]

29. Artym, J.; Zimecki, M. The role of lactoferrin in the proper development of newborns. Postepy Hig. Med. Dosw. 2005, 59, 421-432.

30. Terada, N.; Or, R.; Szepesi, A.; Lucas, J.J.; Gelfand, E.W. Definition of the roles for iron and essential fatty acids in cell cycle progression of normal human T lymphocytes. Exp. Cell Res. 1993, 204, 260-267. [CrossRef]

31. Zhang, C. Essential functions of iron-requiring proteins in DNA replication, repair and cell cycle control. Protein Cell. 2014, 5, 750-760. [CrossRef]

32. Beard, J.L. Iron biology in immune function, muscle metabolism and neuronal functioning. J. Nutr. 2001, 131, 568S-580S. [CrossRef] [PubMed]

33. Dejkhamron, P.; Wejaphikul, K.; Mahatumarat, T.; Silvilairat, S.; Charoenkwan, P.; Saekho, S.; Unachak, K. Vitamin D deficiency and its relationship with cardiac iron and function in patients with transfusion-dependent thalassemia at Chiang Mai University Hospital. Pediatr. Hematol. Oncol. 2018, 35, 52-59. [CrossRef] [PubMed]

34. Tavsan, Z.; Ayar Kayali, H. The Effect of Iron and Copper as an Essential Nutrient on Mitochondrial Electron Transport System and Lipid Peroxidation in Trichoderma harzianum. Appl Biochem. Biotechnol. 2013, 170, 1665-1675. [CrossRef]

35. Aisen, P.; Enns, C.; Wessling-Resnick, M. Chemistry and biology of eukaryotic iron metabolism. Int. J. Biochem. Cell Biol. 2001, 33, 940-959. [CrossRef]

36. Lieu, P.T.; Heiskala, M.; Peterson, P.A.; Yang, Y. The roles of iron in health and disease. Mol. Asp. Med. 2001, 22, 1-87. [CrossRef]

37. Abbaspour, N.; Hurrell, R.; Kelishadi, R. Review on iron and its importance for human health. J. Res. Med. Sci. 2014, 19, 164-174.

38. Bothwell, T.H.; Charlton, R.W. A general approach to the problems of iron deficiency and iron overload in the population at large. Semin Hematol. 1982, 19, 54-67.

39. DeMaeyer, E.; Dallman, P.; Gurney, J.; Hallberg, L.; Sood, S.K.; Srikantia, S.G. Preventing and Controlling Iron Deficiency Anaemia through Primary Health Care: A Guide for Health Administrators and Programme Managers; World Health Organization, Ed.; WHO: Geneva, Switzerland, 1989; 58p.

40. Scholl, T.O.; Reilly, T. Anemia, iron and pregnancy outcome. J. Nutr. 2000, 130, 443-447. [CrossRef]

41. Hytten, F. Blood volume changes in normal pregnancy. Clin. Haematol. 1985, 14, 601-612. [CrossRef]

42. Khoigani, M.G.; Goli, S.; Hasanzadeh, A. The relationship of hemoglobin and hematocrit in the first and second half of pregnancy with pregnancy outcome. Iran. J. Nurs Midwifery Res. 2012, 17 (Suppl. 1), S165-S170.

43. Soma-Pillay, P.; Nelson-Piercy, C.; Tolppanen, H.; Mebazaa, A.; Tolppanen, H.; Mebazaa, A. Physiological changes in pregnancy. Cardiovasc J. Afr. 2016, 27, 89-94. [CrossRef] [PubMed]

44. Laflamme, E.M. Maternal hemoglobin concentration and pregnancy outcome: A study of the effects of elevation in el alto, bolivia. McGill J. Med. 2011, 13, 47. [PubMed] 
45. Rogne, T.; Tielemans, M.J.; Chong, M.F.-F.; Yajnik, C.S.; Krishnaveni, G.V.; Poston, L.; Jaddoe, V.W.V.; Steegers, E.A.P.; Joshi, S.; Chong, Y.-S.; et al. Associations of maternal vitamin B12 concentration in pregnancy with the risks of preterm birth and low birth weight: A systematic review and meta-analysis of individual participant data. Am. J. Epidemiol. 2017, 185, 212-223. [CrossRef] [PubMed]

46. Ciobanu, A.M.; Colibaba, S.; Cimpoca, B.; Peltecu, G.; Panaitescu, A.M. Thrombocytopenia in pregnancy. Maedica 2016, 11, 55-60.

47. Kopeć, I. Hematologic complications during pregnancy. Hematologia 2016, 7, 295-302. [CrossRef]

48. WHO/UNICEF/UNO IDA. Prevention, Assessment and Control. Report of a WHO/UNICEF/UNO Consultation; WHO: Geneva, Switzerland, 1998.

49. Centers for Disease Control (CDC). CDC criteria for anemia in children and childbearing-aged women. Morb. Mortal. Wkly. Rep. 1989, 38, 400-404.

50. Paweł, L.; Rafał, R.; Starzyński, A.S.; Robert Staroń, A.G. Dietary iron deficiency anemia. Kosmos 2014, 63, 373-379.

51. Anderson, G.J.; Frazer, D.M.; McKie, A.T.; Vulpe, C.D.; Smith, A. Mechanisms of haem and non-haem iron absorption: Lessons from inherited disorders of iron metabolism. BioMetals 2005, 18, 339-348. [CrossRef]

52. McKie, A.T.; Barrow, D.; Latunde-Dada, G.O.; Rolfs, A.; Sager, G.; Mudaly, E.; Richardson, C.; Barlow, D.; Bomford, A.; Peters, T.J.; et al. An iron-regulated ferric reductase associated with the absorption of dietary iron. Science 2001, 291, 1755-1759. [CrossRef]

53. Donovan, A.; Brownlie, A.; Dorschner, M.O.; Zhou, Y.; Pratt, S.J.; Paw, B.H.; Phillips, R.B.; Thisse, C.; Thisse, B.; Zon, L.I. The zebrafish mutant gene chardonnay (cdy) encodes divalent metal transporter 1 (DMT-1). Blood 2002, 100, 4655-4659. [CrossRef]

54. Lipiński, P.; Starzyński, R.R.; Gajowiak, A.; Staroń, R. Iron Metabolism- state of the art. Kosm Ser A 2014, 63, 299-308.

55. Wang, X.; Flores, S.R.; Ha, J.-H.; Doguer, C.; Woloshun, R.R.; Xiang, P.; Grosche, A.; Vidyasagar, S.; Collins, J.F. Intestinal DMT1 Is Essential for Optimal Assimilation of Dietary Copper in Male and Female Mice with Iron-Deficiency Anemia. J. Nutr. 2018, 148, 1244-1252. [CrossRef] [PubMed]

56. Espinoza, A.; Le Blanc, S.; Olivares, M.; Pizarro, F.; Ruz, M.; Arredondo, M. Iron, copper, and zinc transport: Inhibition of divalent metal transporter 1 (DMT 1) and human copper transporter 1 (hCTR1) by shRNA. Biol. Trace Elem. Res. 2012, 146, 281-286. [CrossRef] [PubMed]

57. Ha, J.-H.; Doguer, C.; Collins, J.F. Knockdown of copper-transporting ATPase 1 (Atp7a) impairs iron flux in fully-differentiated rat (IEC-6) and human (Caco-2) intestinal epithelial cells. Metallomics 2016, 8, 963-972. [CrossRef]

58. Latunde-Dada, G.O.; Takeuchi, K.; Simpson, R.J.; McKie, A.T. Haem carrier protein 1 (HCP1): Expression and functional studies in cultured cells. FEBS Lett. 2006, 580, 6865-6870. [CrossRef]

59. Macara, I.G.; Hoy, T.G.; Harrison, P.M. The formation of ferritin from apoferritin. Catalytic action of apoferritin. Biochem. J. 1973, 135, 343. [CrossRef]

60. Doguer, C.; Ha, J.-H.; Collins, J.F. Intersection of iron and copper metabolism in the mammalian intestine and liver. Compr. Physiol. 2018, 8, 1433. [CrossRef]

61. Qiu, A.; Jansen, M.; Sakaris, A.; Min, S.H.; Chattopadhyay, S.; Tsai, E.; Sandoval, C.; Zhao, R.; Akabas, M.; Goldman, I.D. Identification of an Intestinal Folate Transporter and the Mol.ecular Basis for Hereditary Folate Malabsorption. Cell 2006, 127, 917-928. [CrossRef]

62. Le, N.T.; Richardson, D.R. Ferroportin1, a new iron export molecule? Int. J. Biochem. Cell Biol. 2002, 34, 103-108. [CrossRef]

63. Vulpe, C.D.; Kuo, Y.-M.; Murphy, T.L.; Cowley, L.; Askwith, C.; Libina, N.; Gitschier, J.; Anderson, G.J. Hephaestin, a ceruloplasmin homologue implicated in intestinal iron transport, is defective in the sla mouse. Nat. Genet. 1999, 21, 195-199. [CrossRef]

64. Donovan, A.; Brownlie, A.; Zhou, Y.; Shepard, J.; Pratt, S.J.; Moynihan, J.; Paw, B.H.; Drejer, A.; Barut, B.; Zapata, A.; et al. Positional cloning of zebrafish ferroportin1 identifies a conserved vertebrate iron exporter. Nature 2000, 403, 776-781. [CrossRef] [PubMed]

65. Daher, R.; Karim, Z. Iron metabolism: State of the art. Transfus Clin. Biol. 2017, 24, 115-119. [CrossRef] [PubMed]

66. Giansanti, F.; Panella, G.; Leboffe, L.; Antonini, G. Lactoferrin from Milk: Nutr. aceutical and Pharmacol.ogical Properties. Pharmaceuticals 2016, 9, 61. [CrossRef] [PubMed] 
67. Nairz, M.; Theurl, I.; Swirski, F.K.; Weiss, G. "Pumping iron"—How macrophages handle iron at the systemic, microenvironmental, and cellular levels. Pflugers Arch. 2017, 469, 397-418. [CrossRef] [PubMed]

68. Sukhbaatar, N.; Weichhart, T. Iron Regulation: Macrophages in Control. Pharmaceuticals 2018, 11, 137. [CrossRef] [PubMed]

69. Nicolas, G.; Bennoun, M.; Devaux, I.; Beaumont, C.; Grandchamp, B.; Kahn, A.; Vaulont, S. Lack of hepcidin gene expression and severe tissue iron overload in upstream stimulatory factor 2 (USF2) knockout mice. Proc. Natl. Acad. Sci. USA 2001, 98, 8780-8785. [CrossRef] [PubMed]

70. Pigeon, C.; Ilyin, G.; Courselaud, B.; Leroyer, P.; Turlin, B.; Brissot, P.; Loréal, O. A new mouse liver-specific gene, encoding a protein homologous to human antimicrobial peptide hepcidin, is overexpressed during Iron overload. J. Biol. Chem. 2001, 276, 7811-7819. [CrossRef]

71. Barrett, J.F.; Whittaker, P.G.; Williams, J.G.; Lind, T. Absorption of non-haem iron from food during normal pregnancy. BMJ 1994, 309, 79-82. [CrossRef]

72. Nemeth, E.; Tuttle, M.S.; Powelson, J.; Vaughn, M.B.; Donovan, A.; Ward, D.M.; Ganze, T.; Kaplan, J. Hepcidin regulates cellular iron efflux by binding to ferroportin and inducing its internalization. Science 2004, 306, 2090-2093. [CrossRef]

73. Wada, H.G.; Hass, P.E.; Sussman, H.H. Transferrin receptor in human placental brush border membranes. J. Biol. Chem. 1979, 254, 12629-12635.

74. Müller, R.; Verma, I.M.; Adamson, E.D. Expression of c-onc genes: C-fos transcripts accumulate to high levels during development of mouse placenta, yolk sac and amnion. EMBO J. 1983, 2, 679-684. [CrossRef] [PubMed]

75. Gambling, L.; Danzeisen, R.; Gair, S.; Lea, R.G.; Charania, Z.; Solanky, N.; Joory, K.D.; Srai, S.K.; McArdle, H.J. Effect of iron deficiency on placental transfer of iron and expression of iron transport proteins in vivo and in vitro. Biochem. J. 2001, 356 (Pt 3), 883-889. [CrossRef]

76. Bastin, J.; Drakesmith, H.; Rees, M.; Sargent, I.; Townsend, A. Localisation of proteins of iron metabolism in the human placenta and liver. Br. J. Haematol. 2006, 134, 532-543. [CrossRef] [PubMed]

77. Ohgami, R.S.; Campagna, D.R.; McDonald, A.; Fleming, M.D. The Steap proteins are metalloreductases. Blood 2006, 108, 1388-1394. [CrossRef] [PubMed]

78. Georgieff, M.K.; Wobken, J.K.; Welle, J.; Burdo, J.R.; Connor, J.R. Identification and localization of divalent metal transporter-1 (DMT-1) in term human placenta. Placenta 2000, 21, 799-804. [CrossRef] [PubMed]

79. McArdle, H.J.; Gambling, L.; Kennedy, C. Iron deficiency during pregnancy: The consequences for placental function and fetal outcome. Proc Nutr. Soc. 2014, 73, 9-15. [CrossRef]

80. Gunshin, H.; Fujiwara, Y.; Custodio, A.O.; Direnzo, C.; Robine, S.; Andrews, N.C. Slc11a2 is required for intestinal iron absorption and erythropoiesis but dispensable in placenta and liver. J. Clin. Invest. 2005, 115, 1258-1266. [CrossRef]

81. Wang, C.-Y.; Jenkitkasemwong, S.; Duarte, S.; Sparkman, B.K.; Shawki, A.; Mackenzie, B.; Knutson, M.D. ZIP8 is an iron and zinc transporter whose cell-surface expression is up-regulated by cellular iron loading. J. Biol. Chem. 2012, 287, 34032-34043. [CrossRef]

82. Cao, C.; Fleming, M.D. The placenta: The forgotten essential organ of iron transport. Nutr. Rev. 2016, 74, 421-431. [CrossRef]

83. Sangkhae, V.; Nemeth, E. Placental iron transport: The mechanism and regulatory circuits. Free Radic Biol. Med. 2019, 133, 254-261. [CrossRef]

84. Kohgo, Y.; Ikuta, K.; Ohtake, T.; Torimoto, Y.; Kato, J. Body iron metabolism and pathophysiology of iron overload. Int. J. Hematol. 2008, 88, 7-15. [CrossRef] [PubMed]

85. Wallace, D.F. The Regulation of Iron Absorption and Homeostasis. Clin. Biochem. Rev. 2016, 37, 51-62. [PubMed]

86. Baker, L.B. Physiology of sweat gland function: The roles of sweating and sweat composition in human health. Temp. Multidiscip Biomed. J. 2019, 6, 211-259. [CrossRef] [PubMed]

87. Gulec, S.; Anderson, G.J.; Collins, J.F. Mechanistic and regulatory aspects of intestinal iron absorption. Am. J. Physiol. Gastrointest. Liver Physiol. 2014, 307, G397. [CrossRef] [PubMed]

88. Bothwell, T.H. Iron requirements in pregnancy and strategies to meet them. Am. J. Clin. Nutr. 2000, 72, 257S-264S. [CrossRef]

89. Johnson-Wimbley, T.D.; Graham, D.Y. Diagnosis and management of iron deficiency anemia in the 21st century. Therap. Adv. Gastroenterol. 2011, 4, 177-184. [CrossRef] 
90. Soppi, E.T. Iron deficiency without anemia-A clinical challenge. Clin. Case Rep. 2018, 6, $1082-1086$. [CrossRef]

91. Rüfer, A.; Criblez, D.; Wuillemin, W.A. Iron-deficiency anemia and gastrointestinal bleeding. Ther. Umschau. 2006, 63, 339-343. [CrossRef]

92. Spottiswoode, N.; Duffy, P.E.; Drakesmith, H. Iron, anemia and hepcidin in malaria. Front Pharmacol. 2014, 5, 125. [CrossRef]

93. Smith, J.L.; Brooker, S. Impact of hookworm infection and deworming on anaemia in non-pregnant populations: A systematic review. Trop. Med. Int. Health 2010, 15, 776-795. [CrossRef]

94. Miller, J.L. Iron deficiency anemia: A common and curable disease. Cold Spring Harb. Perspect. Med. 2013, 3, a011866. [CrossRef] [PubMed]

95. Bartnikas, T.B. Known and potential roles of transferrin in iron biology. Biometals 2012, 25, 677-686. [CrossRef] [PubMed]

96. Naoum, F.A. Iron deficiency in cancer patients. Rev. Bras. Hematol. Hemoter. 2016, 38, 325-330. [CrossRef] [PubMed]

97. Lee, A.I.; Okam, M.M. Anemia in pregnancy. Hematol. Oncol Clin. N. Am. 2011, 25, 241-259. [CrossRef] [PubMed]

98. Charzewska, J. Human NutritionBasics of Nutrition Science; Gawęcki, J., Ed.; Wydawnictwo Naukowe PWN: Warszawa, Poland, 2000; pp. 481-492.

99. Loréal, O.; Cavey, T.; Bardou-Jacquet, E.; Guggenbuhl, P.; Ropert, M.; Brissot, P. Iron, hepcidin, and the metal connection. Front. Pharmacol. 2014, 5, 128. [CrossRef] [PubMed]

100. Menon, A.V.; Chang, J.; Kim, J. Mechanisms of Divalent Metal Toxicity in Affective Disorders. Toxicology 2016, 339, 58-72. [CrossRef]

101. Hubbard, A.C.; Bandyopadhyay, S.; Wojczyk, B.S.; Spitalnik, S.L.; Hod, E.A.; Prestia, K.A. Effect of dietary iron on fetal growth in pregnant mice. Comp. Med. 2013, 63, 127-135.

102. Woodman, A.G.; Mah, R.; Keddie, D.; Noble, R.M.N.; Panahi, S.; Gragasin, F.S.; Lemieux, H.; Bourque, S.L. Prenatal iron deficiency causes sex-dependent mitochondrial dysfunction and oxidative stress in fetal rat kidneys and liver. FASEB J. 2018, 32, 3254-3263. [CrossRef]

103. Harrison-Findik, D.D. Gender-related variations in iron metabolism and liver diseases. World J. Hepatol. 2010, 2, 302-310. [CrossRef]

104. Dignass, A.; Farrag, K.; Stein, J. Limitations of serum ferritin in diagnosing iron deficiency in inflammatory conditions. Int. J. Chronic Dis. 2018, 2018, 9394060. [CrossRef]

105. Hallberg, L. Vitamins and Minerals in Pregnancy and Lactation; Berger, H., Ed.; Raven Press: New York, NY, USA, 1988; pp. 115-127.

106. Seu, M.; Mose, J.C.; Panigoro, R.; Sahiratmadja, E. Anemia prevalence after iron supplementation among pregnant women in midwifes practice of primary health care facilities in eastern indonesia. Anemia 2019, 2019, 1413906. [CrossRef] [PubMed]

107. McMahon, L.P. Iron deficiency in pregnancy. Obstet. Med. 2010, 3, 17-24. [CrossRef] [PubMed]

108. Tangeda, P.R.; Patil, S.; Shastri, N.; Noorali, S.N. Maternal myocardial performance in second trimester of pregnancy with iron deficiency anaemia. J. Clin. Diagn Res. 2016, 10, CC16. [CrossRef]

109. Woodman, A.G.; Care, A.S.; Mansour, Y.; Cherak, S.J.; Panahi, S.; Gragasin, F.S.; Bourque, S.L. Modest and severe maternal iron deficiency in pregnancy are associated with fetal anaemia and organ-specific hypoxia in rats. Sci. Rep. 2017, 7, 46573. [CrossRef] [PubMed]

110. Tayyebi, A.; Poursadeghfard, M.; Nazeri, M.; Pousadeghfard, T. Is there any correlation between migraine attacks and iron deficiency anemia? A case-control study. Int. J. Hematol. Stem Cell Res. 2019, 13, 164-171.

111. Abu-Ouf, N.M.; Jan, M.M. The impact of maternal iron deficiency and iron deficiency anemia on child's health. Saudi Med. J. 2015, 36, 146-149. [CrossRef]

112. Lumish, R.A.; Young, S.L.; Lee, S.; Cooper, E.; Pressman, E.; Guillet, R.; O’Brien, K.O. Gestational iron deficiency is associated with pica behaviors in adolescents. J. Nutr. 2014, 144, 1533-1539. [CrossRef]

113. Breymann, C. Iron deficiency anemia in pregnancy. Semin Hematol. 2015, 52, 339-347. [CrossRef]

114. Milman, N.; Taylor, C.L.; Merkel, J.; Brannon, P.M. Iron status in pregnant women and women of reproductive age in Europe. Am. J. Clin. Nutr. 2017, 106, 1655S-1662S. [CrossRef]

115. Tandon, R.; Jain, A.; Malhotra, P. Management of iron deficiency anemia in pregnancy in india. Indian J. Hematol. Blood Transfus. 2018, 34, 204. [CrossRef] 
116. Milman, N. Iron and pregnancy-A delicate balance. Ann. Hematol. 2006, 85, 559-565. [CrossRef] [PubMed]

117. Zimmermann, M.B.; Hurrell, R.F. Nutritional iron deficiency. Lancet 2007, 370, 511-520. [CrossRef]

118. Black, R.E. Micronutrients in pregnancy. Br. J. Nutr. 2001, 85, S193-S197. [CrossRef] [PubMed]

119. Figueiredo, A.C.M.G.; Gomes-Filho, I.S.; Silva, R.B.; Pereira, P.P.S.; Mata, F.A.F.; Da Lyrio, A.O.; Souza, E.S.; Cruz, S.S.; Pereira, M.G. Maternal anemia and low birth weight: A systematic review and meta-analysis. Nutrients 2018, 10, 601. [CrossRef] [PubMed]

120. Ru, Y.; Pressman, E.K.; Cooper, E.M.; Guillet, R.; Katzman, P.J.; Kent, T.R.; Bacak, S.J.; O’Brien, K.O. Iron deficiency and anemia are prevalent in women with multiple gestations. Am. J. Clin. Nutr. 2016, 104, 1052-1060. [CrossRef]

121. Kaiser, L.; Allen, L.H.; American Dietetic Association. Position of the American Dietetic Association: Nutrition and lifestyle for a healthy pregnancy outcome. J. Am. Diet. Assoc. 2008, 108, 553-561.

122. Khayat, S.; Fanaei, H.; Ghanbarzehi, A. Minerals in pregnancy and lactation: A review Article. J. Clin. Diagn Res. 2017, 11, QE01-QE05. [CrossRef]

123. Cogswell, M.E.; Parvanta, I.; Ickes, L.; Yip, R.; Brittenham, G.M. Iron supplementation during pregnancy, anemia, and birth weight: A randomized controlled trial. Am. J. Clin. Nutr. 2003, 78, 773-781. [CrossRef]

124. Allen, L.H. Biological mechanisms that might underlie iron's effects on fetal growth and preterm birth. J. Nutr. 2001, 131, 581S-589S. [CrossRef]

125. Peña-Rosas, J.P.; De-Regil, L.M.; Garcia-Casal, M.N.; Dowswell, T. Daily oral iron supplementation during pregnancy. Cochrane Database Syst Rev. 2015, 7, CD004736. [CrossRef]

126. Abioye, A.I.; Aboud, S.; Premji, Z.; Etheredge, A.J.; Gunaratna, N.S.; Sudfeld, C.R.; Mongi, R.; Meloney, L.; Darling, A.M.; Noor, R.A.; et al. Iron supplementation affects hematologic biomarker concentrations and pregnancy outcomes among iron-deficient Tanzanian women. J. Nutr. 2016, 146, 1162-1171. [CrossRef] [PubMed]

127. Zhao, G.; Xu, G.; Zhou, M.; Jiang, Y.; Richards, B.; Clark, K.M.; Kaciroti, N.; Georgieff, M.K.; Zhang, Z.; Tardif, T.; et al. Prenatal iron supplementation reduces maternal anemia, iron deficiency, and iron deficiency anemia in a randomized clinical trial in rural china, but iron deficiency remains widespread in mothers and neonates. J. Nutr. 2015, 145, 1916-1923. [CrossRef] [PubMed]

128. Peña-Rosas, J.P.; De-Regil, L.M.; Gomez, M.H.; Flores-Urrutia, M.C.; Dowswell, T. Intermittent oral iron supplementation during pregnancy. Cochrane Database Syst. Rev. 2015, CD009997. [CrossRef] [PubMed]

129. Ziaei, S.; Rahman, A.; Raqib, R.; Lönnerdal, B.; Ekström, E.-C. A prenatal multiple micronutrient supplement produces higher maternal vitamin B-12 concentrations and similar folate, ferritin, and zinc concentrations as the standard 60-mg iron plus 400- $\mu \mathrm{g}$ folic acid supplement in rural bangladeshi women. J. Nutr. 2016, 146, 2520-2529. [CrossRef]

130. Ali, M.K.; Abbas, A.M.; Abdelmagied, A.M.; Mohammed, G.E.; Abdalmageed, O.S. A randomized clinical trial of the efficacy of single versus double-daily dose of oral iron for prevention of iron deficiency anemia in women with twin gestations. J. Matern. Fetal Neonatal Med. 2017, 30, 2884-2889. [CrossRef]

131. Shinar, S.; Skornick-Rapaport, A.; Maslovitz, S. Iron supplementation in twin pregnancy-The benefit of doubling the iron dose in iron deficient pregnant women: A randomized controlled trial. Twin Res. Hum. Genet. 2017, 20, 419-424. [CrossRef]

132. Skoczynska, A.; Kwiecinska, D.; Kielbinski, M.; Lukaszewski, M. Acute iron poisoning in adult female. Hum. Exp. Toxicol. 2007, 26, 663-666. [CrossRef]

133. Wood, J.C. Guidelines for quantifying iron overload. ASH Educ. Progr. B 2014, 2014, 210-215. [CrossRef]

134. Brissot, P.; Ropert, M.; Le Lan, C.; Loréal, O. Non-transferrin bound iron: A key role in iron overload and iron toxicity. Biochim. Biophys Acta Gen. Subj. 2012, 1820, 403-410. [CrossRef]

135. Aydemir, T.B.; Cousins, R.J. The Multiple Faces of the Metal Transporter ZIP14 (SLC39A14). J. Nutr. 2018, 148, 174-184. [CrossRef]

136. Fibach, E.; Rachmilewitz, E.A. Iron overload in hematological disorders. Presse Med. 2017, 46, e296-e305. [CrossRef] [PubMed]

137. Pietrangelo, A. Iron and the liver. Liver Int. 2016, 36, 116-123. [CrossRef] [PubMed]

138. Silver, M.M.; Beverley, D.W.; Valberg, L.S.; Cutz, E.; Phillips, M.J.; Shaheed, W.A. Perinatal hemochromatosis. Clinical, morphologic, and quantitative iron studies. Am. J. Pathol. 1987, 128, 538. [PubMed]

139. Prus, E.; Fibach, E. Effect of iron chelators on labile iron and oxidative status of thalassaemic erythroid cells. Acta Haematol. 2010, 123, 14-20. [CrossRef] 
140. Menon, R. Oxidative stress damage as a detrimental factor in preterm birth pathology. Front. Immunol. 2014, 5, 567. [CrossRef] [PubMed]

141. Collins, J.F. Copper. In Modern Nutrition in Health and Disease, 11th ed.; Ross, A.C., Caballero, B., Cousins, R.J., Tucker, K.L., Ziegler, T.R., Eds.; Lippincott Williams and Wilkins: Philadelphia, PA, USA, 2014; p. 206.

142. Gibson, R.S. Principles of Nutritional Assessment; Oxford University Press: Oxford, UK, 2005; 908p.

143. Łanocha-Arendarczyk, N.; Kosik-Bogacka, D.I.; Copper, C. Mammals and Birds as Bioindicators of Trace Element Contaminations in Terrestrial Environments: An Ecotoxicological Assessment of the Northern Hemisphere; Kalisińska, E., Ed.; Springer International Publishing: Cham, Switzerland, 2019; pp. 125-161.

144. Uauy, R.; Olivares, M.; Gonzalez, M. Essentiality of copper in humans. Am. J. Clin. Nutr. 1998, 67, 952S-959S. [CrossRef]

145. Cetin, I.; Berti, C.; Calabrese, S. Role of micronutrients in the periconceptional period. Hum. Reprod Update. 2010, 16, 80-95. [CrossRef]

146. Lurie, D.G.; Holden, J.M.; Schubert, A.; Wolf, W.R.; Miller-Ihli, N.J. The copper content of foods based on a critical evaluation of published analytical data. J. Food Compos. Anal. 1989, 2, 298-316. [CrossRef]

147. Squitti, R.; Siotto, M.; Polimanti, R. Low-copper diet as a preventive strategy for Alzheimer's disease. Neurobiol. Aging 2014, 35, S40-S50. [CrossRef]

148. Peña, M.M.O.; Lee, J.; Thiele, D.J. A delicate balance: Homeostatic control of copper uptake and distribution. J. Nutr. 1999, 129, 1251-1260. [CrossRef]

149. Krzeptowski, W.; Pierzchała, O.; Lenartowicz, M. Copper metabolism and characteristic of inherited metabolic syndromes caused by copper deficiency and lack of TP7A protein activity. Kosmos 2014, 63, 395-413.

150. Wang, F.; Jiao, P.; Qi, M.; Frezza, M.; Dou, Q.P.; Yan, B. Turning tumor-promoting copper into an anti-cancer weapon via high-throughput chemistry. Curr Med. Chem. 2010, 17, 2685-2698. [CrossRef] [PubMed]

151. Eisses, J.F.; Kaplan, J.H. The mechanism of copper uptake mediated by human CTR1, a mutational analysis. J. Biol. Chem. 2005, 280, 37159-37168. [CrossRef] [PubMed]

152. Gunshin, H.; Mackenzie, B.; Berger, U.V.; Gunshin, Y.; Romero, M.F.; Boron, W.F.; Nussberger, S.; Gollan, J.L.; Hediger, M.A. Cloning and characterization of a proton-coupled mammalian metal-ion transporter. Nature 1997, 388, 482-488. [CrossRef] [PubMed]

153. Kim, H.; Wu, X.; Lee, J. SLC31 (CTR) family of copper transporters in health and disease. Mol. Aspects Med. 2013, 34, 561-570. [CrossRef]

154. Sharp, P.A. Ctr1 and its role in body copper homeostasis. Int. J. Biochem. Cell Biol. 2003, 35, $288-291$. [CrossRef]

155. Wee, N.K.Y.; Weinstein, D.C.; Fraser, S.T.; Assinder, S.J. The mammalian copper transporters CTR1 and CTR2 and their roles in development and disease. Int. J. Biochem. Cell Biol. 2013, 45, 960-963. [CrossRef]

156. Kuo, Y.M.; Zhou, B.; Cosco, D.; Gitschier, J. The copper transporter CTR1 provides an essential function in mammalian embryonic development. Proc. Natl. Acad. Sci. USA 2001, 98, 6836-6841. [CrossRef]

157. Kelner, G.S.; Lee, M.; Clark, M.E.; Maciejewski, D.; McGrath, D.; Rabizadeh, S.; Lyons, T.; Bredesen, D.; Jenner, P.; Maki, R.A. The copper transport protein Atox1 promotes neuronal survival. J. Biol. Chem. 2000, 275, 580-584. [CrossRef]

158. Shike, M. Copper in Parenteral Nutrition. Gastroenterology 2009, 137, S13-S17. [CrossRef]

159. Kunachowicz, H.; Przygoda, B.; Nadolna, I.K. Food Composition and Nutrition Tables; PZWL: Warszawa, Poland, 2017.

160. McArdle, H.J.; Bingham, M.J.; Summer, K.; Ong, T.J. Cu metabolism in the liver. Adv. Exp. Med. Biol. 1999, 448, 29-37. [PubMed]

161. Pisu, P.; Bellovino, D.; Gaetani, S. Copper regulated synthesis, secretion and degradation of ceruloplasmin in a mouse immortalized hepatocytic cell line. Cell Mol. Biol. 2005, 51, OL859-OL867. [PubMed]

162. Boyer, J.L. Bile Formation and Secretion. Compr. Physiol. 2013, 3, 1035.

163. Moore, S.D.; Cox, D.W. Expression in Mouse Kidney of Membrane Copper Transporters Atp7a and Atp7b. Nephron 2002, 92, 629-634. [CrossRef] [PubMed]

164. Frankel, D.A. Supplementation of trace elements in parenteral nutrition: Rationale and recommendations. Nutr. Res. 1993, 13, 583-596. [CrossRef]

165. Bartee, M.Y.; Lutsenko, S. Hepatic copper-transporting ATPase ATP7B: Function and inactivation at the molecular and cellular level. Biometals 2007, 20, 627-637. [CrossRef] 
166. Lee, J.; Prohaska, J.R.; Thiele, D.J. Essential role for mammalian copper transporter Ctr1 in copper homeostasis and embryonic development. Proc. Natl. Acad. Sci. USA 2001, 98, 6842-6847. [CrossRef]

167. Hardman, B.; Manuelpillai, U.; Wallace, E.M.; van de Waasenburg, S.; Cater, M.; Mercer, J.F.B.; Ackland, M.L. Expression and localization of Menkes and Wilson copper transporting ATPases in human placenta. Placenta 2004, 25, 512-517. [CrossRef]

168. Hardman, B.; Michalczyk, A.; Greenough, M.; Camakaris, J.; Mercer, J.F.B.; Ackland, M.L. Hormonal regulation of the Menkes and Wilson copper-transporting ATPases in human placental Jeg-3 cells. Biochem. J. 2007, 402, 241-250. [CrossRef]

169. McArdle, H.J.; Andersen, H.S.; Jones, H.; Gambling, L. Copper and iron transport across the placenta: Regulation and Interactions. J. Neuroendocrinol. 2008, 20, 427-431. [CrossRef]

170. Collins, J.F.; Klevay, L.M. Copper. Adv. Nutr. 2011, 2, 520-522. [CrossRef] [PubMed]

171. Wazir, S.M.; Ghobrial, I. Copper deficiency, a new triad: Anemia, leucopenia, and myeloneuropathy. J. Community Hosp. Intern. Med. Perspect. 2017, 7, 265-268. [CrossRef] [PubMed]

172. Myint, Z.W.; Oo, T.H.; Thein, K.Z.; Tun, A.M.; Saeed, H. Copper deficiency anemia: Review article. Ann. Hematol. 2018, 97, s00277-s018. [CrossRef] [PubMed]

173. Bolognin, S.; Pasqualetto, F.; Mucignat-Caretta, C.; Scancar, J.; Milacic, R.; Zambenedetti, P.; Cozzi, B.; Zatta, P. Effects of a copper-deficient diet on the biochemistry, neural morphology and behavior of aged mice. PLoS ONE 2012, 7, e47063. [CrossRef] [PubMed]

174. Zatta, P.; Frank, A. Copper deficiency and neurological disorders in man and animals. Brain Res. Rev. 2007, 54, 19-33. [CrossRef]

175. Chen, Y.; Saari, J.T.; Kang, Y.J. Weak antioxidant defenses make the heart a target for damage in copper-deficient rats. Free Radic Biol. Med. 1994, 17, 529-536. [CrossRef]

176. Qu, X.; He, Z.; Qiao, H.; Zhai, Z.; Mao, Z.; Yu, Z.; Dai, K. Serum copper levels are associated with bone mineral density and total fracture. J. Orthop. Transl. 2018, 14, 34. [CrossRef]

177. Wang, H.W.; Zhou, B.H.; Zhang, S.; Guo, H.W.; Zhang, J.L.; Zhao, J.; Tian, E.J. Reproductive toxicity in male mice after exposure to high molybdenum and low copper concentrations. Toxicol. Ind. Health 2016, 32, 1598-1606. [CrossRef]

178. Li, Y.; Wang, L.; Schuschke, D.A.; Zhou, Z.; Saari, J.T.; Kang, Y.J. Marginal dietary copper restriction induces cardiomyopathy in rats. J. Nutr. 2005, 135, 2130-2136. [CrossRef]

179. Jiang, Y.; Reynolds, C.; Xiao, C.; Feng, W.; Zhou, Z.; Rodriguez, W.; Tyagi, S.C.; Eaton, J.W.; Saari, J.T.; Kang, Y.J. Dietary copper supplementation reverses hypertrophic cardiomyopathy induced by chronic pressure overload in mice. J. Exp. Med. 2007, 204, 657. [CrossRef]

180. WHO. Copper in Drinking-Water; WHO/SDE/WSH/03.04/88:2004; World Health Organization: Geneva, Switzerland, 2004.

181. Danks, D.M. Copper Deficiency in Humans. Annu. Rev. Nutr. 1988, 8, 235-257. [CrossRef] [PubMed]

182. Liu, X.-Z.; Li, M.; Huang, C.-Y.; Zhang, Y.-Z. Study of effects of copper deficiency on internal organ through a copper deficiency model in rat. Zhonghua Yu Fang Yi Xue Za Zhi 2007, 41, 127-130. [PubMed]

183. Kiilholma, P.; Grönroos, M.; Erkkola, R.; Pakarinen, P.; Näntö, V. The role of calcium, copper, iron and zinc in preterm delivery and premature rupture of fetal membranes. Gynecol. Obstet. Invest. 1984, 17, 194-201. [CrossRef] [PubMed]

184. Kardos, J.; Héja, L.; Simon, Á.; Jablonkai, I.; Kovács, R.; Jemnitz, K. Copper signalling: Causes and consequences. Cell Commun. Signal. 2018, 16, 71. [CrossRef] [PubMed]

185. Yu, L.; Liou, I.W.; Biggins, S.W.; Yeh, M.; Jalikis, F.; Chan, L.; Burkhead, J. Copper deficiency in liver diseases: A case series and pathophysiological considerations. Hepatol. Commun. 2019, 3, 1159. [CrossRef]

186. Tümer, Z. An Overview and Update of ATP7A Mutations leading to Menkes disease and occipital horn syndrome. Hum. Mutat. 2013, 34, 417-429. [CrossRef]

187. Tümer, Z.; Møller, L.B. Menkes disease. Eur. J. Hum. Genet. 2010, 18, 511-518. [CrossRef]

188. Møller, L.; Lenartowicz, M.; Zabot, M.-T.; Josiane, A.; Burglen, L.; Bennett, C.; Riconda, D.; Fisher, R.; Janssens, S.; Mohammed, S.; et al. Clinical expression of Menkes disease in females with normal karyotype. Orphanet J. Rare Dis. 2012, 7, 6. [CrossRef]

189. Gualandi, F.; Sette, E.; Fortunato, F.; Bigoni, S.; De Grandis, D.; Scotton, C.; Selvatici, R.; Neri, M.; Incensi, A.; Liguori, R.; et al. Report of a novel ATP7A mutation causing distal motor neuropathy. Neuromuscul. Disord. 2019, 29, 776-785. [CrossRef] 
190. Chiplunkar, S.; Bindu, P.S.; Nagappa, M.; Bineesh, C.; Govindaraj, P.; Gayathri, N.; Srinivas Bharath, M.M.; Arvinda, H.R.; Mathuranath, P.S.; Sinha, S.; et al. Huppke-Brendel syndrome in a seven months old boy with a novel 2-bp deletion in SLC33A1. Metab. Brain Dis. 2016, 31, 1195-1198. [CrossRef]

191. Martinelli, D.; Dionisi-Vici, C. AP1S1 defect causing MEDNIK syndrome: A new adaptinopathy associated with defective copper metabolism. Ann. N. Y. Acad. Sci. 2014, 1314, 55-63. [CrossRef] [PubMed]

192. Kashanian, M.; Hadizadeh, H.; Faghankhani, M.; Nazemi, M.; Sheikhansari, N. Evaluating the effects of copper supplement during pregnancy on premature rupture of membranes and pregnancy outcome. J. Matern. Fetal Neonatal Med. 2018, 31, 39-46. [CrossRef] [PubMed]

193. Jankowski, M.A.; Uriu-Hare, J.Y.; Rucker, R.B.; Rogers, J.M.; Keen, C.L. Maternal zinc deficiency, but not copper deficiency or diabetes, results in increased embryonic cell death in the rat: Implications for mechanisms underlying abnormal development. Teratology 1995, 51, 85-93. [CrossRef] [PubMed]

194. Kodama, H.; Fujisawa, C.; Bhadhprasit, W. Pathology, clinical features and treatments of congenital copper metabolic disorders-Focus on neurologic aspects. Brain Dev. 2011, 33, 243-251. [CrossRef] [PubMed]

195. Prohaska, J.R. Neurochemical roles of copper as antioxidant or prooxidant. In Metals and Oxidative Damage in Neurological Disorders; Springer: Boston, MA, USA, 1997; pp. 57-75.

196. Lewandowska, M.; Sajdak, S.; Marciniak, W.; Lubiński, J. First trimester serum copper or zinc levels, and risk of pregnancy-induced hypertension. Nutrients 2019, 11, 2479. [CrossRef]

197. Prohaska, J.R.; Brokate, B. The timming of perinatal copper deficiency in mice influences offspring survival. J. Nutr. 2002, 132, 3142-3145. [CrossRef]

198. Vukelić, J.; Kapamadžija, A.; Petrović, D.; Grujić, Z.; Novakov-mikić, A.; Kopitović, V.; Bjelica, A. Variations of serum copper values in pregnancy. Srp. Arh. za Celok. Lek. 2012, 140, 42-46. [CrossRef]

199. Hao, Y.; Pang, Y.; Yan, H.; Zhang, Y.; Liu, J.; Jin, L.; Yan, L.; Chen, D.; Hu, L.; Qin, Y.; et al. Association of maternal serum copper during early pregnancy with the risk of spontaneous preterm birth: A nested case-control study in China. Environ. Int. 2019, 122, 237-243. [CrossRef]

200. Li, P.; Yin, J.; Zhu, Y.; Li, S.; Chen, S.; Sun, T.; Shan, Z.; Wang, J.; Shang, Q.; Li, X.; et al. Association between plasma concentration of copper and gestational diabetes mellitus. Clin. Nutr. 2019, 38, 2922-2927. [CrossRef]

201. Gaetke, L.M.; Chow-Johnson, H.S.; Chow, C.K. Copper: Toxicological relevance and mechanisms. Arch. Toxicol. 2014, 88, 1929. [CrossRef]

202. Pizzino, G.; Irrera, N.; Cucinotta, M.; Pallio, G.; Mannino, F.; Arcoraci, V.; Squadrito, F.; Altavilla, D.; Bitto, A. Oxidative stress: Harms and benefits for human health. Oxid. Med. Cell. Longev. 2017, 2017, 1-13. [CrossRef] [PubMed]

203. Rosencrantz, R.; Schilsky, M. Wilson Disease: Pathogenesis and clinical considerations in diagnosis and treatment. Semin. Liver Dis. 2011, 31, 245-259. [CrossRef] [PubMed]

204. Pfeiffenberger, J.; Beinhardt, S.; Gotthardt, D.N.; Haag, N.; Freissmuth, C.; Reuner, U.; Gauss, A.; Stremmel, W.; Schilsky, M.L.; Ferenci, P.; et al. Pregnancy in Wilson's disease: Management and outcome. Hepatology 2018, 67, 1261-1269. [CrossRef] [PubMed]

205. Reuner, U.; Dinger, J. Pregnancy and Wilson disease: Management and outcome of mother and newborns-Experiences of a perinatal centre. Ann. Transl. Med. 2019, 7, 56. [CrossRef]

206. Russ, E.M.; Raymunt, J. Influence of estrogens on total serum copper and caeruloplasmin. Exp. Biol. Med. 1956, 92, 465-466. [CrossRef]

207. Kambe, T.; Tsuji, T.; Hashimoto, A.; Itsumura, N. The physiological, biochemical, and molecular roles of zinc transporters in zinc homeostasis and metabolism. Physiol. Rev. 2015, 95, 749-784. [CrossRef]

208. Rink, L.; Gabriel, P. Zinc and the immune system. Proc. Nutr. Soc. 2000, 59, 541-552. [CrossRef]

209. Wessells, K.R.; Jorgensen, J.M.; Hess, S.Y.; Woodhouse, L.R.; Peerson, J.M.; Brown, K.H. Plasma zinc concentration responds rapidly to the initiation and discontinuation of short-term zinc supplementation in healthy men. J. Nutr. 2010, 140, 2128-2133. [CrossRef]

210. Hess, S.Y.; Peerson, J.M.; King, J.C.; Brown, K.H. Use of serum zinc concentration as an indicator of population zinc status. Food Nutr. Bull. 2007, 28 (Suppl. 3), S403-S429. [CrossRef]

211. Sekler, I.; Sensi, S.L.; Hershfinkel, M.; Silverman, W.F. Mechanism and regulation of cellular zinc transport. Mol. Med. 2007, 13, 337. [CrossRef]

212. Jackson, M.J. Physiology of zinc: General aspects. In Zinc in Human Biology; Mills, C.F., Ed.; Springer: Berlin/Heidelberg, Germany; New York, NY, USA, 1989; pp. 1-14.

213. Maret, W. Zinc Biochemistry, Physiology, and Homeostasis; Springer: Dordrecht, The Netherlands, 2001. 
214. Gower-Winter, S.D.; Levenson, C.W. Zinc in the central nervous system: From molecules to behavior. BioFactors 2012, 38, 186-193. [CrossRef] [PubMed]

215. Sandstead, H.H.; Frederickson, C.J.; Penland, J.G. History of zinc as related to brain function. J. Nutr. 2000, 130, 496S-502S. [CrossRef] [PubMed]

216. Merck, V.M. The Merck Veterinary Manual: A Handbook of Diagnosis, Therapy and Disease Prevention and Control for the Veterinarian, 6th ed.; Merck \& Co., Inc.: Fort Kenalworth, NJ, USA, 1986.

217. Barceloux, D.G. Zinc. J. Toxicol. Clin. Toxicol. 1999, 37, 279-292. [CrossRef] [PubMed]

218. Kay, A.R.; Toth, K. Is zinc a neuromodulator? Sci. Signal. 2008, 1, re3. [CrossRef]

219. Mocchegiani, E.; Muzzioli, M.; Giacconi, R. Zinc, metallothioneins, immune responses, survival and ageing. Biogerontology 2000, 1, 133-143. [CrossRef]

220. Solomons, N.W. Update on zinc biology. Ann. Nutr. Metab. 2013, 62, 8-17. [CrossRef]

221. Hunt, C.D.; Johnson, P.E.; Herbel, J.; Mullen, L.K. Effects of dietary zinc depletion on seminal volume and zinc loss, serum testosterone concentrations, and sperm morphology in young men. Am. J. Clin. Nutr. 1992, 56, 148-157. [CrossRef]

222. Dardenne, M.; Pleau, J.M.; Nabarra, B.; Lefrancier, P.; Derrien, M.; Choay, J.; Bach, J.F. Contribution of zinc and other metals to the biological activity of the serum thymic factor. Proc. Natl. Acad. Sci. USA 1982, 79, 5370-5373. [CrossRef]

223. Gammoh, N.Z.; Rink, L. Zinc in Infection and Inflammation. Nutrients 2017, 9, 624. [CrossRef]

224. Tainer, J.A.; Getzoff, E.D.; Richardson, J.S.; Richardson, D.C. Structure and mechanism of copper, zinc superoxide dismutase. Nature 1983, 306, 284-287. [CrossRef]

225. Olechnowicz, J.; Tinkov, A.; Skalny, A.; Suliburska, J. Zinc status is associated with inflammation, oxidative stress, lipid, and glucose metabolism. J. Physiol. Sci. 2018, 68, 19-31. [CrossRef] [PubMed]

226. Boron, B.; Hupert, J.; Barch, D.H.; Fox, C.C.; Friedman, H.; Layden, T.J.; Mobarhan, S. Effect of zinc deficiency on hepatic enzymes regulating vitamin A status. J. Nutr. 1988, 118, 995-1001. [CrossRef]

227. Zhai, Q.; Narbad, A.; Chen, W. Dietary strategies for the treatment of cadmium and lead toxicity. Nutrients 2015, 7, 552-571. [CrossRef]

228. Gibson, R.S.; King, J.C.; Lowe, N. A review of dietary zinc recommendations. Food Nutr. Bull. 2016, 37, 443-460. [CrossRef]

229. Maret, W. Zinc biochemistry: From a single zinc enzyme to a key element of life. Adv. Nutr. 2013, 4, 82-91. [CrossRef]

230. Tian, X.; Zheng, Y.; Li, Y.; Shen, Z.; Tao, L.; Dou, X.; Qian, J.; Shen, H. Psychological stress induced zinc accumulation and up-regulation of ZIP14 and metallothionein in rat liver. BMC Gastroenterol. 2014, 14, 32. [CrossRef]

231. Sas, B.; Bremner, I. Effect of acute stress on the absorption and distribution of zinc and on zn-metallothionein production in the liver of the chick. J. Inorg. Biochem. 1979, 11, 67-76. [CrossRef]

232. Yonova, D.; Vazelov, E.; Tzatchev, K. Zinc status in patients with chronic renal failure on conservative and peritoneal dialysis treatment. Hippokratia 2012, 16, 356-359. [PubMed]

233. Mohommad, M.K.; Zhou, Z.; Cave, M.; Barve, A.; McClain, C.J. Zinc and liver disease. Nutr. Clin. Pract. 2012, 27, 8. [CrossRef] [PubMed]

234. Henderson, L.M.; Brewer, G.J.; Dressman, J.B.; Swidan, S.Z.; DuRoss, D.J.; Adair, C.H.; Barnett, J.L.; Berardi, R.R. Effect of intragastric $\mathrm{pH}$ on the absorption of oral zinc acetate and zinc oxide in young healthy volunteers. J. Parenter. Enteral Nutr. 1995, 19, 393-397. [CrossRef]

235. Pallauf, J.; Kramer, K.; Markwitan, A.; Ebel, D. The effect of a supplement of citric acid on the bioavailability of zinc from corn germ. Z. Ernahr. 1990, 29, 27-38. [CrossRef] [PubMed]

236. Sandstrom, B.; Almgren, A.; Kivisto, B.; Cederblad, A. Effect of protein level and protein source on zinc absorption in humans. J. Nutr. 1989, 119, 48-53. [CrossRef] [PubMed]

237. Ghishan, F.K.; Stroop, S.; Meneely, R. The effect of lactose on the intestinal absorption of calcium and zinc in the rat during maturation. Pediatr. Res. 1982, 16, 566-568. [CrossRef] [PubMed]

238. Argiratos, V.; Samman, S. The effect of calcium carbonate and calcium citrate on the absorption of zinc in healthy female subjects. Eur. J. Clin. Nutr. 1994, 48, 198-204.

239. Hambidge, K.M.; Miller, L.V.; Westcott, J.E.; Sheng, X.; Krebs, N.F. Zinc bioavailability and homeostasis. Am. J. Clin. Nutr. 2010, 91, 1478S-1483S. [CrossRef] 
240. Krittaphol, W.; Bailey, K.B.; Pongcharoen, T.; Winichagoon, P.; Gibson, R.S. Low zinc, iron, and calcium intakes of Northeast Thai school children consuming glutinous rice-based diets are not exacerbated by high phytate. Int. J. Food Sci. Nutr. 2006, 57, 520-528. [CrossRef]

241. Sandström, B.; Davidsson, L.; Cederblad, Å.; Lönnerdal, B. Oral iron, dietary ligands and zinc absorption. J. Nutr. 1985, 115, 411-414. [CrossRef]

242. Institute of Medicin (US) Panel on Micronutrients. Dietary reference intakes for vitamin, A.; vitamin, K. In Arsenic, Boron, Chromium, Copper, Iodine, Iron, Manganese, Molybdenum, Nickel, Silicon, Vanadium, and Zinc; National Academies Press (US): Washington, DC, USA, 2001.

243. Giroux, E.; Schechter, P.J.; Schoun, J. Diminished albumin binding of zinc in serum of pregnant women. Clin. Sci. Mol. Med. 1976, 51, 545-549. [CrossRef]

244. World Health Organization. Food and Agriculture Organization of the United Nations, International Atomic Energy Agency. In Trace Elements in Human Nutrition and Health; World Health Organization: Geneva, Switzerland, 1996; 343p.

245. King, J.C.; Shames, D.M.; Woodhouse, L.R. Zinc homeostasis in humans. J. Nutr. 2000, 130, 1360S-1366S. [CrossRef]

246. Fukada, T.; Kambe, T. Molecular and genetic features of zinc transporters in physiology and pathogenesis. Met. Integr. Biomet. Sci. 2011, 3, 662-674. [CrossRef]

247. Cousins, R.J.; McMahon, R.J. Integrative Aspects of Zinc Transporters. J. Nutr. 2000, 130, 1384S-1387S. [CrossRef] [PubMed]

248. Han, M.; Chang, J.; Kim, J. Loss of divalent metal transporter 1 function promotes brain copper accumulation and increases impulsivity. J. Neurochem. 2016, 138, 918-928. [CrossRef] [PubMed]

249. Turnlund, J.R.; King, J.C.; Keyes, W.R.; Gong, B.; Michel, M.C. A stable isotope study of zinc absorption in young men: Effects of phytate and a-cellulose. Am. J. Clin. Nutr. 1984, 40, 1071-1077. [CrossRef] [PubMed]

250. Tapiero, H.; Tew, K.D. Trace elements in human physiology and pathology: Zinc and metallothioneins. Biomed. Pharmacother. 2003, 57, 399-411. [CrossRef]

251. Smith, K.T.; Failla, M.L.; Cousins, R.J. Identification of albumin as the plasma carrier for zinc absorption by perfused rat intestine. Biochem. J. 1979, 184, 627-633. [CrossRef] [PubMed]

252. Gachot, B.; Tauc, M.; Morat, L.; Poujeol, P. Zinc uptake by proximal cells isolated from rabbit kidney: Effects of cysteine and histidine. Pflugers Arch. Eur. J. Physiol. 1991, 419, 583-587. [CrossRef]

253. Aiken, S.P.; Horn, N.M.; Saunders, N.R. Effects of amino acids on zinc transport in rat erythrocytes. J. Physiol. 1992, 445, 69-80. [CrossRef]

254. Coyle, P.; Philcox, J.C.; Carey, L.C.; Rofe, A.M. Metallothionein: The multipurpose protein. Cell Mol. Life Sci. 2002, 59, 627-647. [CrossRef]

255. Drozd, A.; Wojewska, D.; Peris-Díaz, M.D.; Jakimowicz, P.; Krężel, A. Crosstalk of the structural and zinc buffering properties of mammalian metallothionein-2. Metallomics 2018, 10, 595-613. [CrossRef]

256. Lynes, M.A.; Zaffuto, K.; Unfricht, D.W.; Marusov, G.; Samson, J.S.; Yin, X. The physiological roles of extracellular metallothionein. Exp. Biol. Med. 2006, 231, 1548-1554. [CrossRef]

257. Ruttkay-Nedecky, B.; Nejdl, L.; Gumulec, J.; Zitka, O.; Masarik, M.; Eckschlager, T.; Stiborova, M.; Adam, V.; Kizek, R. The role of metallothionein in oxidative stress. Int. J. Mol. Sci. 2013, 14, 6044-6066. [CrossRef] [PubMed]

258. Saad, A.A.; El-Sikaily, A.; Kassem, H. Metallothionein and glutathione content as biomarkers of metal pollution in mussels and local fishermen in Abu Qir Bay, Egypt. J. Heal. Pollut. 2016, 6, 50. [CrossRef] [PubMed]

259. Rice, J.M.; Zweifach, A.; Lynes, M.A. Metallothionein regulates intracellular zinc signaling during CD4+ T cell activation. BMC Immunol. 2016, 17, 13. [CrossRef] [PubMed]

260. Sutherland, D.E.; Willans, M.J.; Stillman, M.J. Single domain metallothioneins: Supermetalation of human MT 1a. J. Am. Chem. Soc. 2012, 134, 3290-3299. [CrossRef]

261. Krężel, A.; Maret, W. The functions of metamorphic metallothioneins in zinc and copper metabolism. Int. J. Mol. Sci. 2017, 18, 1237. [CrossRef] [PubMed]

262. Nicolas, G.; Bennoun, M.; Porteu, A.; Mativet, S.; Beaumont, C.; Grandchamp, B.; Sirito, M.; Sawadogo, M.; Kahn, A.; Vaulont, S. Severe iron deficiency anemia in transgenic mice expressing liver hepcidin. Proc. Natl. Acad. Sci. USA 2002, 99, 4596-4601. [CrossRef]

263. Baltaci, A.K.; Yuce, K. Zinc transporter proteins. Neurochem. Res. 2018, 43, 517-530. [CrossRef] 
264. Liuzzi, J.P.; Cousins, R.J. Mammmalin zinc transporters. Annu. Rev. Nutr. 2004, 24, 151-172. [CrossRef]

265. Huang, L.; Tepaamorndech, S. The SLC30 family of zinc transporters-A review of current understanding of their biological and pathophysiological roles. Mol. Aspects Med. 2013, 34, 548-560. [CrossRef]

266. Grüngreiff, K.; Reinhold, D.; Wedemeyer, H. The role of zinc in liver cirrhosis. Ann. Hepatol. 2016, 15, 7-16. [CrossRef]

267. Faa, G.; Nurchi, V.M.; Ravarino, A.; Fanni, D.; Nemolato, S.; Gerosa, C.; Eyken, P.V.; Geboes, K. Zinc in gastrointestinal and liver disease. Coord Chem. Rev. 2008, 252, 1257-1269. [CrossRef]

268. Paterson, P.G.; Mas, A.; Sarkar, B.; Zlotkin, S.H. The influence of zinc-binding ligands in fetal circulation on zinc clearance across the in situ perfused guinea pig placenta. J. Nutr. 1991, 121, 338-344. [CrossRef] [PubMed]

269. Ford, D. Intestinal and placental zinc transport pathways. Proc. Nutr. Soc. 2004, 63, 21-29. [CrossRef] [PubMed]

270. Carey, L.C.; Coyle, P.; Philcox, J.C.; Rofe, A.M. Ethanol decreases zinc transfer to the fetus in normal but not metallothionein-null mice. Alcohol. Clin. Exp. Res. 2000, 24, 1236-1240. [CrossRef]

271. Cousins, R.J.; Liuzzi, J.P.; Lichten, L.A. Mammalian zinc transport, trafficking, and signals. J. Biol. Chem. 2006, 281, 24085-24089. [CrossRef]

272. Lewicka, I.; Kocyłowski, R.; Grzesiak, M.; Gaj, Z.; Oszukowski, P.; Suliburska, J. Selected trace elements concentrations in pregnancy and their possible role-Literature review. Ginekol. Pol. 2017, 88, 509-514. [CrossRef]

273. Mocchegiani, E.; Romeo, J.; Malavolta, M.; Costarelli, L.; Giacconi, R.; Diaz, L.E.; Marcos, A. Zinc: Dietary intake and impact of supplementation on immune function in elderly. Age (Dordr) 2013, 35, 839-860. [CrossRef]

274. Caulfield, L.E.; Zavaleta, N.; Shankar, A.H.; Merialdi, M. Potential contribution of maternal zinc supplementation during pregnancy to maternal and child survival. Am. J. Clin. Nutr. 1998, 68, 499S-508S. [CrossRef]

275. Gapys, B.; Raszeja-Specht, A.; Bielarczyk, H. Role of zinc in physiological and pathological processes of the body. J. Lab. Diagn. Diagn Lab. 2014, 50, 45-52.

276. Prasad, A.S. Discovery of human zinc deficiency: Its impact on human health and disease. Adv. Nutr. 2013, 4, 176-190. [CrossRef]

277. Buamah, P.K.; Russell, M.; Bates, G.; Ward, A.M.; Skillen, A.W. Maternal zinc status: A determination of central nervous system malformation. BJOG An. Int. J. Obstet. Gynaecol. 1984, 91, 788-790. [CrossRef] [PubMed]

278. Lehti, K.K. Stillbirth rates and folic acid and zinc status in low-socioeconomic pregnant women of brazilian amazon. Nutrition 1993, 9, 156-158. [PubMed]

279. Scholl, T.O.; Hediger, M.L.; Schall, J.I.; Fischer, R.L.; Khoo, C.-S. Low zinc intake during pregnancy: Its association with preterm and very preterm delivery. Am. J. Epidemiol. 1993, 137, 1115-1124. [CrossRef]

280. Siva, S.; Rubin, D.T.; Gulotta, G.; Wroblewski, K.; Pekow, J. Zinc deficiency is associated with poor clinical outcomes in patients with inflammatory bowel disease. Inflamm. Bowel Dis. 2017, 23, 152. [CrossRef] [PubMed]

281. Osna, N.A.; Donohue, T.M., Jr.; Kharbanda, K.K. Alcoholic liver disease: Pathogenesis and current management. Alcohol Res. 2017, 38, 147.

282. Mahajan, S.K. Zinc in kidney disease. J. Am. CollNutr. 1989, 8, 296-304. [CrossRef]

283. Russell, R.M. Vitamin and mineral supplements in the management of liver disease. Med. Clin. North. Am. 1979, 63, 537-544. [CrossRef]

284. Donangelo, C.M.; King, J.C. Maternal zinc intakes and homeostatic adjustments during pregnancy and lactation. Nutrients 2012, 4, 782-798. [CrossRef]

285. Terrin, G.; Berni Canani, R.; Di Chiara, M.; Pietravalle, A.; Aleandri, V.; Conte, F.; Curtis, M.D. Zinc in early life: A key element in the fetus and preterm neonate. Nutrients 2015, 7, 10427-10446. [CrossRef]

286. Karimi, A.; Bagheri, S.; Nematy, M.; Saeidi, M. Zinc deficiency in pregnancy and fetal—neonatal outcomes and impact of the supplements on pregnancy outcomes. MashhadUniv Med. Sci. 2012, 3, 77-83.

287. Sultana, M.; Jahan, N.; Sultana, N.; Quraishi, S.B.; Chowdhury, T.R. Preterm delivery: Role of zinc. J. Bangladesh Soc. Physiol. 2010, 5, 27-33. [CrossRef] 
288. Apgar, J. Effect of zinc deficiency on maintenance of pregnancy in the rat. J. Nutr. 1970, 100, 470-476. [CrossRef] [PubMed]

289. McKenzie, J.M.; Fosmire, G.J.; Sandstead, H.H. Zinc feficiency during the latter third of pregnancy: Effects on fetal rat brain, liver, and placenia. J. Nutr. 1975, 105, 1466-1475. [CrossRef] [PubMed]

290. Golub, M.S.; Keen, C.L.; Gershwin, M.E.; Hendrickx, A.G. Developmental zinc deficiency and behavior. J. Nutr. 1995, 125, 2263S-2271S. [CrossRef] [PubMed]

291. Nossier, S.A.; Naeim, N.E.; El-Sayed, N.A.; Abu Zeid, A.A. The effect of zinc supplementation on pregnancy outcomes: A double-blind, randomised controlled trial, Egypt. Br. J. Nutr. 2015, 114, 274-285. [CrossRef] [PubMed]

292. Prawirohartono, E.P.; Nyström, L.; Nurdiati, D.S.; Hakimi, M.; Lind, T. The impact of prenatal vitamin A and zinc supplementation on birth size and neonatal survival-A double-blind, randomized controlled trial in a rural area of Ind.onesia. Int. J. Vitam Nutr. Res. 2013, 83, 14-25. [CrossRef] [PubMed]

293. Wang, H.; Hu, Y.-F.; Hao, J.-H.; Chen, Y.-H.; Su, P.-Y.; Wang, Y.; Yu, Z.; Fu, L.; Xu, Y.Y.; Zhang, C.; et al. Maternal zinc deficiency during pregnancy elevates the risks of fetal growth restriction: A population-based birth cohort study. Sci. Rep. 2015, 5, 11262. [CrossRef]

294. Merialdi, M.; Caulfield, L.E.; Zavaleta, N.; Figueroa, A.; Dominici, F.; DiPietro, J.A. Randomized controlled trial of prenatal zinc supplementation and the development of fetal heart rate. Am. J. Obstet. Gynecol. 2004, 190, 1106-1112. [CrossRef]

295. Merialdi, M.; Caulfield, L.E.; Zavaleta, N.; Figueroa, A.; DiPietro, J.A. Adding zinc to prenatal iron and folate tablets improves fetal neurobehavioral development. Am. J. Obstet. Gynecol. 1999, 180, 483-490. [CrossRef]

296. Merialdi, M.; Caulfield, L.E.; Zavaleta, N.; Figueroa, A.; Costigan, K.A.; Dominici, F.; Dipietro, J.A. Randomized controlled trial of prenatal zinc supplementation and fetal bone growth. Am. J. Clin. Nutr. 2004, 79, 826-830. [CrossRef]

297. Wilson, R.L.; Leemaqz, S.Y.; Goh, Z.; McAninch, D.; Jankovic-Karasoulos, T.; Leghi, G.E.; Phillips, J.A.; Colafella, K.M.; Tran, C.; O'Leary, S.; et al. Zinc is a critical regulator of placental morphogenesis and maternal hemodynamics during pregnancy in mice. Sci. Rep. 2017, 7, 15137. [CrossRef] [PubMed]

298. Reynolds, L.P.; Caton, J.S.; Redmer, D.A.; Grazul-Bilska, A.T.; Vonnahme, K.A.; Borowicz, P.P.; Luther, J.S.; Wallace, J.M.; Wu, G.; Spencer, T.E. Evidence for altered placental blood flow and vascularity in compromised pregnancies. J. Physiol. 2006, 572, 51-58. [CrossRef] [PubMed]

299. Ota, E.; Mori, R.; Middleton, P.; Tobe-Gai, R.; Mahomed, K.; Miyazaki, C.; Bhutta, Z.A. Zinc supplementation for improving pregnancy and infant outcome. Cochrane Database Syst. Rev. 2015, 2015, CD000230. [CrossRef] [PubMed]

300. Karamali, M.; Heidarzadeh, Z.; Seifati, S.-M.; Samimi, M.; Tabassi, Z.; Talaee, N.; Bahardoost, H.; Asemi, Z. Zinc supplementation and the effects on pregnancy outcomes in gestational diabetes: A randomized, double-blind, placebo-controlled trial. Exp. Clin. Endocrinol. Diabetes 2015, 124, 28-33. [CrossRef]

301. Zahiri sorouri, Z.; Sadeghi, H.; Pourmarzi, D. The effect of zinc supplementation on pregnancy outcome: A randomized controlled trial. J. Matern. Fetal Neonatal Med. 2016, 29, 2194-2198. [CrossRef]

302. Chaffee, B.W.; King, J.C. Effect of zinc supplementation on pregnancy and infant outcomes: A systematic review. Paediatr. Perinat. Epidemiol. 2012, 26, 118-137. [CrossRef]

303. Mori, R.; Ota, E.; Middleton, P.; Tobe-Gai, R.; Mahomed, K.; Bhutta, Z.A. Zinc supplementation for improving pregnancy and infant outcome. In Cochrane Database of Systematic Reviews; Mori, R., Ed.; John Wiley \& Sons, Ltd.: Chichester, UK, 2012.

304. King, J.C. Determinants of maternal zinc status during pregnancy. Am. J. Clin. Nutr. 2000, 71, 1334S-1343S. [CrossRef]

305. Goodnight, W.; Newman, R. Society of maternal-fetal medicine. Optimal nutrition for improved twin pregnancy outcome. Obstet. Gynecol. 2009, 114, 1121-1134. [CrossRef]

306. Mahomed, K.; Bhutta, Z.A.; Middleton, P. Zinc supplementation for improving pregnancy and infant outcome. In Cochrane Database of Systematic Reviews; Mahomed, K., Ed.; John Wiley \& Sons, Ltd.: Chichester, UK, 2007.

307. Campbell, D.M.; MacGillivray, I.; Tuttle, S. Maternal nutrition in twin pregnancy. Acta Genet. Med. Gemellol (Roma) 1982, 31, 221-227. [CrossRef]

308. Fosmire, G.J. Zinc toxicity. Am. J. Clin. Nutr. 1990, 51, 225-227. [CrossRef] 
309. Plum, L.M.; Rink, L.; Haase, H. The essential toxin: Impact of zinc on human health. Int. J. Environ. Res. Public Health 2010, 7, 1342-1365. [CrossRef] [PubMed]

310. Environmental Health Criteria 221. Zinc; FIRST Draft Prepared; World Health Organization: Geneva, Switzerland, 2001.

311. Scheers, N. Regulatory effects of $\mathrm{Cu}, \mathrm{Zn}$, and Ca on Fe absorption: The intricate play between nutrient transporters. Nutrients 2013, 5, 957-970. [CrossRef] [PubMed]

312. Ha, J.-H.; Doguer, C.; Wang, X.; Flores, S.R.; Collins, J.F. High-iron consumption impairs growth and causes copper-deficiency anemia in weanling Sprague-Dawley rats. PLoS ONE 2016, 11, e0161033. [CrossRef] [PubMed]

313. Chen, H.; Huang, G.; Su, T.; Gao, H.; Attieh, Z.K.; McKie, A.T.; Anderson, G.A.; Vulpe, C.D. Decreased hephaestin activity in the intestine of copper-deficient mice causes systemic iron deficiency. J. Nutr. 2006, 136, 1236-1241. [CrossRef]

314. Reeves, P.G.; DeMars, L.C.S.; Johnson, W.T.; Lukaski, H.C. Dietary copper deficiency reduces iron absorption and duodenal enterocyte hephaestin protein in male and female Rats. J. Nutr. 2005, 135, 92-98. [CrossRef]

315. Muckenthaler, M.U.; Rivella, S.; Hentze, M.W.; Galy, B. A red carpet for iron metabolism. Cell 2017, 168, 344-361. [CrossRef]

316. Toxqui, L.; Vaquero, M.P. Chronic iron deficiency as an emerging risk factor for osteoporosis: A hypothesis. Nutrients 2015, 7, 2324-2344. [CrossRef]

317. Ha, J.-H.; Doguer, C.; Collins, J.F. Consumption of a high-iron diet disrupts homeostatic regulation of intestinal copper absorption in adolescent mice. Am. J. Physiol. Gastrointest. Liver Physiol. 2017, 313, G353. [CrossRef]

318. Collins, J.F.; Prohaska, J.R.; Knutson, M.D. Metabolic crossroads of iron and copper. Nutr. Rev. 2010, 68, 133-147. [CrossRef]

319. Chan, W.Y.; Rennert, O.M. The role of copper in iron metabolism. Ann. Clin. Lab. Sci. 1980, 10, 338-344.

320. Gulec, S.; Collins, J.F. Molecular mediators governing iron-copper interactions. Annu. Rev. Nutr. 2014, 34, 95-116. [CrossRef] [PubMed]

321. Harris, E.D. The iron-copper connection: The link to ceruloplasmin grows stronger. Nutr. Rev. 1995, 53, 170-173. [CrossRef] [PubMed]

322. Ha, J.-H.; Doguer, C.; Flores, S.R.L.; Wang, T.; Collins, J.F. Progressive increases in dietary iron are associated with the emergence of pathologic disturbances of copper homeostasis in growing rats. J. Nutr. 2018, 148, 373-378. [CrossRef] [PubMed]

323. Klevay, L.M. IHD from copper deficiency: A unified theory. Nutr. Res. Rev. 2016, 29, 172-179. [CrossRef] [PubMed]

324. Kedzierska, K.; Bober, J.; Ciechanowski, K.; Golembiewska, E.; Kwiatkowska, E.; Nocen, I.; Dołegowska, B.; Dutkiewicz, G.; Chlubek, D. Copper modifies the activity of sodium-transporting systems in erythrocyte membrane in patients with essential hypertension. Biol. Trace Elem. Res. 2005, 107, 021-032. [CrossRef]

325. Broderius, M.; Mostad, E.; Wendroth, K.; Prohaska, J.R. Levels of plasma ceruloplasmin protein are markedly lower following dietary copper deficiency in rodents. Comp. Biochem. Physiol. C Toxicol. Pharmacol. 2010, 151, 473. [CrossRef]

326. Fields, M.; Lewis, C.G. Hepatic iron overload may contribute to hypertriglyceridemia and hypercholesterolemia in copper-deficient rats. Metabolism 1997, 46, 377-381. [CrossRef]

327. Zhao, M.; Matter, K.; Laissue, J.A.; Zimmermann, A. Copper/zinc and manganese superoxide dismutase immunoreactivity in hepatic iron overload diseases. Histol Histopathol. 1995, 10, 925-935.

328. Patel, B.N.; David, S. A novel glycosylphosphatidylinositol-anchored form of ceruloplasmin is expressed by mammalian astrocytes. J. Biol. Chem. 1997, 272, 20185-20190. [CrossRef]

329. Sebio, R.M.; Ferrarotti, N.; Lairion, F.; Magriñá, C.S.; Fuda, J.; Torti, H.; Boveris, A.; Repetto, M.G. Brain oxidative stress in rat with chronic iron or copper overload. J. Inorg. Biochem. 2019, 199, 110799. [CrossRef]

330. Lan, A.P.; Chen, J.; Chai, Z.F.; Hu, Y. The neurotoxicity of iron, copper and cobalt in Parkinson's disease through ROS-mediated mechanisms. BioMetals 2016, 29, 665-678. [CrossRef] [PubMed]

331. Troost, F.J.; Brummer, R.-J.M.; Dainty, J.R.; Hoogewerff, J.A.; Bull, V.J.; Saris, W.H. Iron supplements inhibit zinc but not copper absorption in vivo in ileostomy subjects. Am. J. Clin. Nutr. 2003, 78, 1018-1023. [CrossRef] [PubMed] 
332. Christian, P.; Khatry, S.K.; LeClerq, S.C.; Ram Shrestha, S.; Kimbrough-Pradhan, E.; West, K.P. Iron and zinc interactions among pregnant Nepali women. Nutr. Res. 2001, 21, 141-148. [CrossRef]

333. Saaka, M. Combined iron and zinc supplementation improves haematologic status of pregnant women in Upper West Region of Ghana. Ghana Med. J. 2012, 46, 225-233.

334. Saaka, M.; Oosthuizen, J.; Beatty, S. Effect of prenatal zinc supplementation on birthweight. J. Health Popul. Nutr. 2009, 27, 619-631. [CrossRef] [PubMed]

335. Harvey, L.J.; Dainty, J.R.; Hollands, W.J.; Bull, V.J.; Hoogewerff, J.A.; Foxall, R.J.; McAnena, L.; Strain, J.J.; Fairweather-Tait, S. Effect of high-dose iron supplements on fractional zinc absorption and status in pregnant women. Am. J. Clin. Nutr. 2007, 85, 131-136. [CrossRef]

336. Peters, A.J.; Keen, C.L.; Lönnerdal, B.; Hurley, L.S. Zinc-vitamin a interaction in pregnant and fetal rats: Supplemental vitamin a does not prevent zinc-deficiency-induced teratogenesis. J. Nutr. 1986, 116, 1765-1771. [CrossRef]

337. O'Brien, K.O.; Zavaleta, N.; Caulfield, L.E.; Wen, J.; Abrams, S.A. Prenatal iron supplements impair zinc absorption in pregnant Peruvian women. J. Nutr. 2000, 130, 2251-2255. [CrossRef]

338. Whittaker, P. Iron and zinc interactions in humans. Am. J. Clin. Nutr. 1998, 68, 442S-446S. [CrossRef]

339. Bodiga, S.; Krishnapillai, M.N. Concurrent repletion of iron and zinc reduces intestinal oxidative damage in iron- and zinc-deficient rats. World J. Gastroenterol. 2007, 13, 5707-5717. [CrossRef]

340. Garrick, M.D.; Singleton, S.T.; Vargas, F.; Kuo, H.C.; Zhao, L.; Knöpfel, M.; Davidson, T.; Costa, M.; Paradkar, P.; Roth, J.A.; et al. DMT-1, Which metals does it transport? Biol. Res. 2006, 39, 79-85. [CrossRef] [PubMed]

341. Kordas, K.; Stoltzfus, R.J. New evidence of iron and zinc interplay at the enterocyte and neural tissues. J. Nutr. 2004, 134, 1295-1298. [CrossRef] [PubMed]

342. Bowers, K.; Srai, S.K.S. The trafficking of metal ion transporters of the Zrt- and Irt-like protein family. Traffic 2018, 19, 813-822. [CrossRef] [PubMed]

343. Solomons, N.W.; Jacob, R.A. Studies on the bioavailability of zinc in humans: Effects of heme and nonheme iron on the absorption of zinc. Am. J. Clin. Nutr. 1981, 34, 475-482. [CrossRef]

344. Solomons, N.W.; Pineda, O.; Viteri, F.; Sandstead, H.H. Studies on the bioavailability of zinc in humans: Mechanism of the intestinal interaction of nonheme iron and zinc. J. Nutr. 1983, 113, 337-349. [CrossRef]

345. Khoushabi, F.; Shadan, M.R.; Miri, A.; Sharifi-Rad, J. Determination of maternal serum zinc, iron, calcium and magnesium during pregnancy in pregnant women and umbilical cord blood and their association with outcome of pregnancy. Mater. Sociomed 2016, 28, 104-107. [CrossRef]

346. Campbell-Brown, M.; Ward, R.J.; Haines, A.P.; North, W.R.; Abraham, R.; McFadyen, I.R.; Turnlund, J.R.; King, J.C. Zinc and copper in Asian pregnancies-is there evidence for a nutritional deficiency? Br. J. Obstet. Gynaecol. 1985, 92, 875-885. [CrossRef]

347. Breskin, M.W.; Worthington-Roberts, B.S.; Knopp, R.H.; Brown, Z.; Plovie, B.; Mottet, N.K.; Mills, J.L. First trimester serum zinc concentrations in human pregnancy. Am. J. Clin. Nutr. 1983, 38, 943-953. [CrossRef]

348. Ziaei, S.; Janghorban, R.; Shariatdoust, S.; Faghihzadeh, S. The effects of iron supplementation on serum copper and zinc levels in pregnant women with high-normal hemoglobin. Int. J. Gynecol. Obstet. 2008, 100, 133-135. [CrossRef]

349. Andersen, H.S.; Gambling, L.; Holtrop, G.; McArdle, H.J. Effect of dietary copper deficiency on iron metabolism in the pregnant rat. Br. J. Nutr. 2007, 97, 239-246. [CrossRef]

350. Gambling, L.; Danzeisen, R.; Fosset, C.; Andersen, H.S.; Dunford, S.; Srai, S.K.S.; McArdle, H.J. Iron and copper interactions in development and the effect on pregnancy outcome. J. Nutr. 2003, 133, 1554S-1556S. [CrossRef] [PubMed]

351. Shidfar, F.; Ameri, A.; Keshavarz, S.; Djalali, M. Effect of iron supplements on serum copper status in pregnant women in Islamshahr. Iran. J. Endocrinol. Metab. 2003, 5, 299-305.

352. Donangelo, C.M.; Woodhouse, L.R.; King, S.M.; Viteri, F.E.; King, J.C. Supplemental zinc lowers measures of iron status in young women with low iron reserves. J. Nutr. 2002, 132, 1860-1864. [CrossRef]

353. de Brito, N.J.N.; Rocha, É.D.; de Araújo Silva, A.; Costa, J.B.S.; França, M.C.; das Graças Almeida, M.; Brandão-Neto, J. Oral zinc supplementation decreases the serum iron concentration in healthy schoolchildren: A pilot study. Nutrients 2014, 6, 3460-3473. [CrossRef] [PubMed] 
354. Antunes, M.F.R.; Leite, L.D.; Rocha, É.D.M.; Brito, N.J.N.; França, M.C.; Silva, C.A.B.; Almeida, M.G.; de Rezende, A.A.; Marchini, J.S.; Brandão-Neto, J. Competitive interaction of zinc and iron after venous and oral zinc administration in eutrophic children. Trace Elem. Electrolytes. 2010, 27, 185-191. [CrossRef]

355. Wieringa, F.T.; Berger, J.; Dijkhuizen, M.A.; Hidayat, A.; Ninh, N.X.; Utomo, B.; Wasantwisut, E.; Winichagoon, P. Combined iron and zinc supplementation in infants improved iron and zinc status, but interactions reduced efficacy in a multicountry trial in southeast Asia. J. Nutr. 2007, 137, 466-471.

356. Holmes, J.B.; Kroeun, H.; Houghton, L.A.; Gibson, R.S.; Harding, K.B.; De-Regil, L.M.; Kraemer, K.; Barr, S.I.; Karakochuk, C.D. Including $60 \mathrm{mg}$ elemental iron in a multiple micronutrient supplement blunts the increase in serum zinc after 12 weeks of daily supplementation in predominantly anemic, nonpregnant Cambodian women of reproductive age. J. Nutr. 2019, 149, 1503-1510. [CrossRef]

357. Nguyen, P.; Grajeda, R.; Melgar, P.; Marcinkevage, J.; Flores, R.; Ramakrishnan, U.; Martorell, R. Effect of zinc on efficacy of iron supplementation in improving iron and zinc status in women. J. Nutr. Metab. 2012, 2012, 216179. [CrossRef]

358. Davidsson, L.; Almgren, A.; Sandström, B.; Hurrell, R.F. Zinc absorption in adult humans: The effect of iron fortification. Br. J. Nutr. 1995, 74, 417-425. [CrossRef]

359. Shaw, C.F.; Savas, M.M.; Petering, D.H. Ligand substitution and sulfhydryl reactivity of metallothionein. Methods Enzymol. 1991, 205, 401-414.

360. Merza, H.; Sood, N.; Sood, R. Idiopathic hyperzincemia with associated copper deficiency anemia: A diagnostic dilemma. Clin. Case Rep. 2015, 3, 819-822. [CrossRef] [PubMed]

361. Sutton, L.; Vusirikala, M.; Chen, W. Hematogone hyperplasia in copper deficiency. Am. J. Clin. Pathol. 2009, 132, 191-199. [CrossRef] [PubMed]

362. Prasad, R.; Hawthorne, B.; Durai, D.; McDowell, I. Zinc in denture adhesive: A rare cause of copper deficiency in a patient on home parenteral nutrition. BMJ Case Rep. 2015, 2015, bcr2015211390. [CrossRef] [PubMed]

363. Deur, C.J.; Stone, M.J.; Frenkel, E.P. Trace metals in hematopoiesis. Am. J. Hematol. 1981, 11, $309-331$. [CrossRef]

364. Percival, S.S. Neutropenia caused by copper deficiency: Possible mechanisms of action. Nutr. Rev. 1995, 53, 59-66. [CrossRef]

365. Paik, H.Y.; Joung, H.; Lee, J.Y.; Lee, H.K.; King, J.C.; Keen, C.L. Serum extracellular superoxide dismutase activity as an indicator of zinc status in humans. Biol. Trace Elem. Res. 1999, 69, 45-57. [CrossRef]

366. Davis, C.D.; Milne, D.B.; Nielsen, F.H. Changes in dietary zinc and copper affect zinc-status indicators of postmenopausal women, notably, extracellular superoxide dismutase and amyloid precursor proteins. Am. J. Clin. Nutr. 2000, 71, 781-788. [CrossRef] [PubMed]

367. Aggarwal, A.; Bhatt, M. Advances in treatment of Wilson disease. Tremor Other Hyperkinet. Mov. 2018 , 8, 525. [CrossRef]

368. Kathawala, M.; Hirschfield, G.M. Insights into the management of Wilson's disease. Therap. Adv. Gastroenterol. 2017, 10, 889-905. [CrossRef]

369. Wiggelinkhuizen, M.; Tilanus, M.E.C.; Bollen, C.W.; Houwen, R.H.J. Systematic review: Clinical efficacy of chelator agents and zinc in the initial treatment of Wilson disease. Aliment. Pharmacol. Ther. 2009, 29, 947-958. [CrossRef]

370. Walshe, J.M.; Munro, N.A.R. Zinc-induced deterioration in Wilson's disease aborted by treatment with penicillamine, dimercaprol, and a novel zero copper diet. Arch. Neurol. 1995, 52, 10-11. [CrossRef]

371. Malik, A.; Khawaja, A.; Sheikh, L. Wilson's disease in pregnancy: Case series and review of literature. BMC Res. Notes. 2013, 6, 421. [CrossRef] [PubMed]

372. Wu, X.; Liu, Z.; Guo, J.; Wan, C.; Zhang, T.; Cui, H.; Yang, F.; Gao, X. Influence of dietary zinc and copper on apparent mineral retention and serum biochemical indicators in young male mink (Mustela vison). Biol. Trace Elem. Res. 2015, 165, 59-66. [CrossRef]

373. Eckert, G.E.; Greene, L.W.; Carstens, G.E.; Ramsey, W.S. Copper status of ewes fed increasing amounts of copper from copper sulfate or copper proteinate. J. Anim Sci. 1999, 77, 244-249. [CrossRef] [PubMed]

374. Du, Z.; Hemken, R.W.; Jackson, J.A.; Trammell, D.S. Utilization of copper in copper proteinate, copper lysine, and cupric sulfate using the rat as an experimental model. J. Anim Sci. 1996, 74, 1657-1667. [CrossRef] [PubMed] 
375. Zetzsche, A.; Schunter, N.; Zentek, J.; Pieper, R. Accumulation of copper in the kidney of pigs fed high dietary zinc is due to metallothionein expression with minor effects on genes involved in copper metabolism. J. Trace Elem. Med. Biol. 2016, 35, 1-6. [CrossRef] [PubMed]

376. Baecker, T.; Mangus, K.; Pfaender, S.; Chha1qbra, R.; Boeckers, T.M.; Grabrucker, A.M. Loss of COMMD1 and copper overload disrupt zinc homeostasis and influence an autism-associated pathway at glutamatergic synapses. BioMetals 2014, 27, 715-730. [CrossRef]

377. Reinstein, N.H.; Lönnerdal, B.; Keen, C.L.; Hurley, L.S. Zinc-copper interactions in the pregnant rat: Fetal outcome and maternal and fetal zinc, copper and iron. J. Nutr. 1984, 114, 1266-1279. [CrossRef]

378. Kinnamon, K.E. Some independent and combined effects of copper, molybdenum, and zinc on the placental transfer of zinc-65 in the Rat. J. Nutr. 1963, 81, 312-320. [CrossRef]

379. Garg, H.K.; Singhal, K.C.; Arshad, Z. Effect of oral zinc supplementation on copper and haemoglobin levels in pregnant women. Indian J. Physiol. Pharmacol. 1994, 38, 272-276.

(C) 2020 by the authors. Licensee MDPI, Basel, Switzerland. This article is an open access article distributed under the terms and conditions of the Creative Commons Attribution (CC BY) license (http://creativecommons.org/licenses/by/4.0/). 